\title{
The Pricing and Performance of Supercharged IPOs
}

\author{
Alexander Edwards \\ Rotman School of Management \\ University of Toronto \\ alex.edwards@,rotman.utoronto.ca \\ Michelle Hutchens \\ Gies College of Business \\ University of Illinois \\ mlh80@,illinois.edu \\ Sonja Olhoft Rego* \\ Kelley School of Business \\ Indiana University \\ sorego@indiana.edu
}

October 2018

\begin{abstract}
${ }^{*}$ Corresponding author. All authors gratefully acknowledge helpful comments from Anne Beatty, Sam Bonsall, James Chyz, Dave Guenther, Erin Henry, Jeff Hoopes, Linda Krull, Steve Matsunaga, Lil Mills (the editor), James Myers, Linda Myers, Kyle Peterson, Gregg Polasky, Gord Richardson, Steven Savoy, Max Todtenhaupt (discussant), Andy Van Buskirk, Jaron Wilde, Ryan Wilson, Wuyang Zhao, two anonymous referees, seminar participants at Ohio State University, the University of Oregon, the University of Tennessee, the University of Toronto, the University of Munster Capital Markets Conference, and the University of Texas at Austin Tax Readings Group. We are also grateful for the research assistance provided by Junwei Xia and Stefan Mitrovic. Edwards acknowledges the financial support of the Social Sciences and Humanities Research Council of Canada and the Rotman School of Management. Hutchens is thankful for financial support from the Kelley School of Business and the Gies College of Business. Rego appreciates financial support from the Kelley School of Business and the Deloitte Foundation.
\end{abstract}




\title{
The Pricing and Performance of Supercharged IPOs
}

\begin{abstract}
This study examines a new form of initial public offerings, "supercharged" IPOs, where a firm organized pre-IPO as a pass-through entity undergoes a series of transactions that steps-up the adjusted tax basis of the IPO firm's assets. This step-up imposes tax liabilities on pre-IPO owners but also creates significant future tax benefits for the firm; the average anticipated deferred tax asset is \$486 million (\$13 per share) for our sample of supercharged IPO firms. Pursuant to tax receivable agreements, supercharged IPO firms pay a large portion of these tax benefits to pre-IPO owners as they are realized in the future. Future firm performance must be sufficiently strong for the IPO firm and the pre-IPO owners to realize the future tax benefits created by the supercharged transaction structure. We hypothesize and provide evidence of higher IPO offer prices and stronger future performance for supercharged IPO firms relative to traditional IPO firms.
\end{abstract}

Keywords: supercharged IPO; deferred tax assets; up-C; tax receivable agreement JEL Classifications: G14, G32, G34, H25 


\section{Introduction}

The significant tax benefits available in acquisitions of pass-through entities, such as partnerships (in contrast to acquisitions of $\mathrm{C}$ corporations), are well known in the investment banking community and among academic researchers (e.g., Erickson and Wang 2007; Scholes, Wolfson, Erickson, Hanlon, Maydew, and Shevlin 2015). In contrast, few are aware of the significant tax benefits available in the initial public offerings (IPOs) of pass-through entities. As highlighted in Scholes et al. (2015), the unusual structure of the Blackstone Group L.P. IPO in 2007 generated more than $\$ 1$ billion of tax benefits, the vast majority of which were allocated to Blackstone's pre-IPO partners. Given the increasing prevalence of this lucrative transaction structure, we examine the tax benefits generated by, and the pricing and future performance of, this new IPO transaction structure, which we refer to as "supercharged" IPOs.

In a traditional IPO, a private firm "goes public" by issuing shares in exchange for cash from new investors on the open market. The issuance of new shares generates no direct tax costs or tax benefits for the firm or the pre-IPO owners. In a supercharged IPO, a private firm engages in a series of transactions with the intention of creating future tax benefits. Only private firms that are organized as pass-through entities, such as partnerships or limited liability companies (LLCs), can undertake this IPO transaction structure. ${ }^{1}$ Pre-IPO owners can exchange their pass-through ownership units for shares in the new public firm at various points in time (on the IPO date or

\footnotetext{
${ }^{1}$ We define a "supercharged IPO" as an IPO of an entity previously taxed as a pass-through that includes: (1) a stepup in the adjusted tax basis of assets to fair market value, and (2) a tax receivable agreement requiring the new public company to pay a percentage of future tax savings to pre-IPO owners. We note that some prior research, most notably Fleischer and Staudt (2014), refer to all IPO transactions that involve tax receivable agreements as "supercharged IPOs." Our sample includes 50 IPOs of entities previously taxed as pass-through entities that meet our definition of supercharged IPO during our sample period. We identified six additional IPOs that include tax receivable agreements, but these transactions involve firms that were organized before the IPO as $\mathrm{C}$ corporations, which do not have the same tax arbitrage opportunities as pass-through entities (because they are subject to two levels of tax). Thus, we exclude these observations from our sample of supercharged IPOs.
} 
after). These exchanges trigger "step-up" in the IPO firm's tax basis in assets to fair market value, which generates future tax benefits (in the form of future amortization or depreciation deductions) but also imposes tax costs on the pre-IPO owners at the time of the exchange. A contract commonly referred to as a "tax receivable agreement" (TRA), executed in conjunction with the IPO, provides for the split of the future tax benefits between the pre-IPO owners (typically 85-90 percent) and the public firm (typically 10-15 percent). ${ }^{2}$ These arrangements allow pre-IPO owners to retain a large portion of the value of assets created under their ownership (e.g., goodwill) that could otherwise be discounted by new IPO investors.

The net effect of a "supercharged" transaction on pre-IPO owners (as they exchange passthrough ownership units for new public company stock) is the imposition of current tax costs in exchange for contingent, future benefits. For pre-IPO owners to realize net benefits from supercharging an IPO, the public firm must have sufficient taxable income in the future to realize the tax benefits and make payments to the pre-IPO owners, as provided in the TRA. Thus, the decision to supercharge an IPO should be indicative of pre-IPO owners' expectations for the future prospects of the firm. The tax receivable agreement should also act as a commitment mechanism, aligning the pre-IPO owners' interests with those of the public firm and its shareholders, for the duration of the TRA. If new IPO investors understand the incentives and consequences of supercharging, we expect higher offer prices (and less IPO underpricing on the first day of trading) for supercharged IPOs, compared to traditional IPOs. However, if investors do not distinguish between supercharged and traditional IPOs, then we expect no differences in pricing.

We begin our empirical analyses by providing descriptive information about the magnitudes of the expected and realized tax benefits for our sample of 50 supercharged IPO firms

\footnotetext{
${ }^{2}$ In our sample of supercharged IPOs, every transaction but one allocated 85 percent of the tax benefits to the preIPO owners. In the only exception, the TRA required that 90 percent of the tax benefits be paid to pre-IPO owners.
} 
that went public between 2004 and 2015. Based on disclosures included in Form S-1 filings, supercharged IPO firms anticipate realizing total future tax benefits of $\$ 485.72$ million (\$12.99 per share) on average. This amount is economically significant, especially when compared to the mean enterprise value of $\$ 1.663$ billion ( $\$ 19.35$ per share) at the time of IPO. Additionally, supercharged IPO firms report in proforma financial statements a mean increase in deferred tax assets of $\$ 183.89$ million (\$4.58 per share) at IPO, consistent with a substantial proportion (\$183.89 / \$485.72 $\approx 37$ percent) of the expected exchanges occurring upon IPO. Lastly, review of subsequent Form 10-K filings indicates that the payments to pre-IPO owners during the three years following IPO range from $\$ 0$ to $\$ 52$ million per year, with average total payments of $\$ 11$ million (\$0.23 per share) during the three years post-IPO. Taken together, these figures indicate the anticipated tax benefits generated by supercharged IPO transactions are relatively large, but only a small fraction are actually paid to pre-IPO owners in the three years post-IPO.

We next compare how supercharged and traditional IPOs are priced at IPO (i.e., IPO offer prices) and after the first day of trading (i.e., IPO underpricing, as measured by the percentage change in stock price). Our regression analyses reveal the mean offer price for a supercharged IPO is approximately 17 percent higher than that for a traditional IPO, consistent with supercharged IPO firms issuing stock at significantly higher offer prices. We perform similar analyses examining IPO underpricing on the first day of trading, but do not observe significant differences for supercharged and traditional IPOs. While supercharged IPOs fetch higher initial offer prices, the percentage change in stock price on the first day of trading is similar to that of traditional IPOs.

Our findings are consistent with pre-IPO owners possessing private information about future firm performance, which leads them to supercharge their IPOs to reap future tax benefits. If this private information is correct, then we expect the realized future performance of supercharged 
IPO firms to be superior to that of traditional IPO firms. Such a finding would contrast prior research, which generally documents poor financial performance in the period following traditional IPOs (e.g., Ritter 1991). Results from tests that compare the future performance of supercharged and traditional IPO firms indicate that supercharged IPO firms report earnings before income taxes that are 6.6 cents per share higher than that of traditional IPO firms in the post-IPO period. These findings are consistent with pre-IPO owners supercharging transactions when they expect the firm to experience superior firm performance in the post-IPO period.

We also examine the future stock performance of supercharged IPO firms relative to traditional IPO firms. Given that we observe higher offer prices for firms that supercharge their IPOs, we would expect lower future stock returns if supercharging is merely a mechanism for preIPO owners to extract value from new IPO investors. Alternatively, if supercharging is indicative of pre-IPO owners expecting strong future performance but those expectations are not fully incorporated into offer prices, we would expect higher future stock returns for supercharged (as compared to traditional) IPO firms. However, if investors correctly impound pre-IPO owners' expectations for strong future performance into offer prices, we would expect future stock returns for supercharged IPO firms to not differ from those of traditional IPO firms. Consistent with the final interpretation, we find that supercharged IPO firms experience two-month and one-year stock returns that are not statistically different from those of traditional IPO firms. We caution readers that this evidence is merely suggestive, as we are hesitant to accept the null hypothesis.

In supplemental tests we investigate whether the tax receivable agreements that underlie supercharged IPOs act as alternative mechanisms to "lockup provisions" in alleviating moral hazard problems, and for ensuring that pre-IPO owners remain committed to the new public firm in the post-IPO period. Lockup provisions are frequently used to restrict pre-IPO owners from 
selling their shares for a period of time following IPO. These restrictions alleviate moral hazard problems by aligning pre-IPO owners' incentives with those of the firm and its new, post-IPO shareholders (Brav and Gompers 2003). ${ }^{3}$ We contend that TRAs should align pre-IPO owners' incentives because future payments to the pre-IPO owners are contingent on the firm's future performance. If the market recognizes TRAs as a commitment mechanism, then we expect the supercharged IPOs with fewer shares subject to lockup provisions to have higher offer prices than other supercharged IPOs. Consistent with this prediction we find that supercharged IPO firms with weaker lockup provisions account for the higher IPO offer prices in our primary tests.

Our study contributes to the literature that examines how taxes influence asset prices and transaction structure, especially studies focusing on tax benefit-splitting. Following 1993 legislation permitting tax deductions for goodwill amortization, Ayers, Lefanowicz, and Robinson (2000) and Henning and Shaw (2000) find that acquirers are willing to pay higher prices for target firms when transactions are structured to generate step-up in asset basis. Erickson and Wang (2000 and 2007) also provide evidence of higher acquisition prices when transactions are structured to generate step-up, but these studies focus on subsidiary sales and acquisitions of S corporations, respectively. Our research differs from these studies because we examine asset pricing in the context of IPOs that are structured to generate step-up, where 85-90 percent of the tax benefits are contractually allocated to the pre-IPOs owners, a practice that some critics have deemed abusive. In contrast to such claims, our analyses suggest that supercharging an IPO does not simply shift value from new IPO investors to pre-IPO investors. Instead, we provide evidence that supercharging aligns incentives between pre-IPO owners and new IPO investors and is associated with superior future firm performance compared to similar, traditional IPO firms.

\footnotetext{
${ }^{3}$ We include restricted stock ownership in our measure of lockup as this type of stock ownership imposes similar restrictions on pre-IPO owners from selling their shares.
} 
Overall, our findings indicate that organizing new businesses as pass-through entities, such as LLCs, can produce large tax benefits when part (or all) of the business is sold via IPO. These tax benefits are usually not available to $\mathrm{C}$ corporations, as the two levels of income tax that they are subject to typically generate costs that exceed the benefits of the supercharged IPO transaction structure. The significant tax benefits available to owners of pass-through entities in the IPO setting (as documented in this study), in conjunction with the tax benefits available in acquisitions of pass-through entities (e.g., Erickson and Wang 2007; Scholes et al. 2015), jointly indicate that entrepreneurs should consider organizing and operating as pass-through entities to maximize the potential tax benefits available to them in the future.

\section{Background \& Hypothesis Development}

\subsection{Transaction Structure of Traditional and Supercharged IPOs}

The decision to become a publicly-traded company represents a major step in the life of a firm. In most traditional IPOs, privately-owned businesses that are organized as C corporations issue new shares of capital stock in exchange for cash from new investors. This transaction structure has no direct tax consequences for pre-IPO owners unless they sell any of their pre-IPO shares, which would trigger capital gains taxes on realized gains from the sale of stock.

In recent years some private firms organized as pass-through entities, such as partnerships or LLCs, have started "supercharging" their IPOs. ${ }^{4}$ Prior to a supercharged IPO, the private firm

\footnotetext{
${ }^{4}$ Shobe (2017) suggests there are three ways to execute a "supercharged" IPO, a Section 338(h)(10) election, an Up$\mathrm{C}$, and an Up-PTP. However, our discussion of the transaction (and our sample) reflect only Up-Cs and Up-PTPs (i.e., the transactions available to pass-through entities). A Section 338(h)(10) election steps-up the tax basis of assets; however, the limitations of Section 338(h)(10) make the transaction structure unappealing. To qualify for Section $338(\mathrm{~h})(10)$ treatment, the acquirer must purchase at least 80 percent of the stock from the seller within a 12-month period, and the seller must own at least 80 percent of the stock of the subsidiary before the sale. Further, a 338(h)(10) transaction is taxed as an "asset sale," where the realized gains are treated as part capital gain and part ordinary income to the seller, depending on the types of assets deemed to have been sold. Additionally, a Section 338(h)(10) election may not be tax efficient depending on the seller's basis in assets as compared to basis in subsidiary stock (Erickson and Wang 2000). Lastly, the tax arbitrage available to pass-through entities is not available to C Corporations.
} 
engages in a series of transactions with the intention of creating future tax benefits. Importantly, most supercharged IPO transactions organize a new, shell $\mathrm{C}$ corporation to issue shares to the public as part of the IPO process, while the pre-IPO firm's operating assets remain in the passthrough entity. The pre-IPO owners also enter into a tax receivable agreement with the new $\mathrm{C}$ corporation. Executed in conjunction with an IPO, an exchange agreement allows pre-IPO owners to exchange their pass-through ownership units for new $\mathrm{C}$ corporation stock. These exchanges trigger both the step-up in asset basis (creating tax benefits in the form of future tax deductions that are subject to ordinary tax rates), and also immediate tax liabilities for pre-IPO owners who are treated as selling pass-through ownership units at fair market value. The gains from sales of pass-through units are typically subject to relatively low capital gains tax rates. These exchanges can occur at the time of IPO or over an extended period of time, potentially deferring some or all of the tax payments by pre-IPO owners to the future. In this respect, supercharged IPOs are similar to traditional IPOs, where pre-IPO owners can defer tax costs until they sell their pre-IPO shares in the future (but not avoid such costs altogether).

The most important difference between supercharged and traditional IPOs is that supercharged IPOs step-up the pass-through entity's basis in assets (via a Section 743(b) basis adjustment), while traditional IPOs do not. This step-up not only generates future tax benefits that offset some or all of the capital gains tax liabilities incurred by pre-IPO owners in supercharged transactions, but also avoids any potential double taxation that can occur in traditional IPOs of C corporations, if/when the new public company sells the assets that were not stepped-up to fair market value. Figure 1 illustrates the series of transactions that underlie most supercharged IPOs. Appendix B provides excerpts from the S-1 disclosures for two recent supercharged IPOs.

Proponents of supercharged IPOs contend the transaction structure generates net benefits 
for both new IPO investors and pre-IPO owners through tax receivable agreements, which allocate the future tax benefits (as they are realized) between the new IPO investors (10-15 percent) and pre-IPO owners (85-90 percent). Positive future taxable income is necessary for the realization of these tax benefits. Thus, some proponents also claim TRAs align pre-IPO owners' incentives with those of new IPO investors because they only generate cash payments to pre-IPO owners if the IPO firm is profitable in the future (e.g., Bilsky and Goodman 2015).

Critics of supercharged IPOs have also focused their attention on the TRAs. They argue that the allocation of future tax benefits to pre-IPO owners constitutes an opportunistic transfer of IPO firm value from new IPO investors to pre-IPO owners, since the future tax benefits are typically material and economically significant. In our sample of supercharged IPO firms, the mean amount of related party payables disclosed (accrued) under the TRA constitutes 25 (9) percent of IPO enterprise value. ${ }^{5}$ Consistent with criticisms that TRAs shift value to pre-IPO owners, 46 of 50 supercharged IPOs in our sample include acceleration clauses, i.e., clauses that require IPO firms to pay all remaining TRA payments upon early termination, material breach, or change in control of the IPO firm. Consistent with criticisms that these transactions are confusing and misleading to new investors, we also observe substantial variation in whether and how the related party payables are disclosed or recorded. ${ }^{6}$

Other critics characterize supercharged IPOs as opportunistic tax arbitrage that takes

\footnotetext{
${ }^{5}$ Table 2 reports the estimated step-up in asset basis by firm. The estimated related party payable under the TRA is 85 percent of the estimated step-up for all firms except National CineMedia, Inc., whose TRA is for 90 percent of the estimated step-up. Mean amounts are based on the 44 supercharged IPOs that disclose and/or record an estimated value in pro forma financial statements. Most disclosures do not specify if amounts are discounted to net present value. ${ }^{6}$ Firms must follow SFAS 5 when deciding whether to recognize or disclose a contingent liability for the related party payable. The firm accrues a related party payable if it is probable and reasonably estimable, but only discloses the payable if it is reasonably possible. Gleason and Mills (2002) suggests that audit partners interpret recognition of a SFAS 5 liability as subsuming the disclosure requirement (i.e., disclosure is not required if a contingency is recognized in the financial statements).
} 
advantage of differences in tax rates for pre-IPO owners and IPO firms and thus in net reduces government tax revenues (e.g., Fleischer and Staudt 2014; Shobe 2017). Shobe (2017) also argues that the legal basis for supercharged IPOs (as defined in this paper) is "questionable at best". ${ }^{7}$ This questionable legal basis creates a potential cost for owners that choose to supercharge an IPO, as the benefits could be overturned by tax authorities. See Shobe (2017), Polsky and Rosenzweig (2016), and Fleischer and Staudt (2014) for more extensive discussions of the legal aspects underlying supercharged IPO transactions.

Figure 2 compares the outcomes of traditional and supercharged IPOs based on a variety of assumptions, including how the tax benefits generated by a supercharged IPO are priced. ${ }^{8}$ All five scenarios assume the pre-IPO firm has unrecorded intangible assets that are worth $\$ 100$ and the net value of the remainder of the firm is zero. Column (1) illustrates the benchmark "No IPO" case, where pre-IPO owners hold onto their shares rather than take the firm public. In this case, the net value of the firm is $\$ 100$ (i.e., the unrecorded intangible) and the net value to pre-IPO owners [in row (9)] is $\$ 100$ because there are no tax costs associated with holding onto shares.

In the remaining columns, we consider the consequences associated with various IPO transaction structures. In Columns (2) and (3) we assume that investors have complete information and pre-IPO owners sell (exchange) all ownership interests at IPO. Given these assumptions, new investors are willing to pay $\$ 100$ for all shares of the IPO firm. Column (2) presents the results for a traditional IPO where the pre-IPO owner sells their entire ownership interest at IPO. In this case, given a capital gains tax rate of 15 percent, the pre-IPO owner pays capital gains tax of $\$ 15$ (= 15

\footnotetext{
${ }^{7}$ Consistent with Shobe's (2017) criticisms, many of the Form S-1s for supercharged IPOs include language stating the step-up in basis could be challenged by the IRS. For example, see the "Risk Factors" disclosure from Go Daddy's Form S-1 in Appendix B. Nonetheless, a search by the authors did not yield any examples of the IRS challenging these transactions.

${ }^{8}$ Figure 2 is based (in part) on an example in Fleisher and Staudt (2014).
} 
percent of $\$ 100$ ) related to the sale of stock, where the gain is assumed to equal the total IPO proceeds of $\$ 100$. As a result, the net value of a traditional IPO to the pre-IPO owner [row (9)] is $\$ 85(=\$ 100$ less $\$ 15)$.

Column (3) presents the results for a supercharged IPO, where the pre-IPO owner exchanges their ownership interests at IPO and the new IPO investors are willing to pay $\$ 100$ for all shares of the firm. Here, the sale or exchange of the original ownership interest not only triggers a step-up in tax basis of IPO firm assets (i.e., $\$ 100$ intangible asset) but also a related capital gains tax for the pre-IPO owner $(\$ 15=15$ percent of $\$ 100)$. Given a corporate tax rate of 35 percent, the step-up in basis creates $\$ 35(=35$ percent $\times \$ 100)$ of future tax benefits (undiscounted) for the IPO firm. ${ }^{9}$ If the firm is able to deduct all amortization expense related to the new intangible asset evenly over 15 years, and given a 5 percent discount rate, the net present value of the future tax deductions is $\$ 24.22 .{ }^{10}$ Using the typical $85 / 15$ allocation of tax benefits in most TRAs, Column (3) allocates 85 percent (\$20.59) of the future tax benefits (\$24.22) to the pre-IPO owners and 15 percent $(\$ 3.63)$ to the new investors. As the pre-IPO owner receives these payments $(\$ 20.59)$ in the future, s/he will pay additional capital gains tax of $\$ 3.09$ (= 15 percent of $\$ 20.59) .{ }^{11}$ Thus, the

\footnotetext{
${ }^{9}$ This difference between the capital gains tax rate (15 percent) at the pre-IPO owner level, as compared to the corporate tax rate (35 percent) at the IPO firm level, creates the tax arbitrage opportunity. If the pre-IPO owner, however, is a $\mathrm{C}$ corporation rather than an individual, the benefits of the supercharged IPO transaction structure are substantially reduced, since the capital gain would then be subject to the higher 35 percent corporate tax rate.

${ }^{10}$ If the firm is not able to utilize the future tax deductions (e.g., because they are not profitable in the future), then the present value of future tax benefits [row (5)] would be $\$ 0$, which would reduce the net value of a supercharged IPO for pre-IPO owners [row (9)] to $\$ 85(=\$ 100+\$ 0$ - $\$ 15)$ because the pre-IPO owner would still pay the capital gains tax of $\$ 15$ at IPO (related to step-up in basis), but the future tax benefits would be worthless. In this case, the net value of traditional and supercharged IPOs is $\$ 85$. Thus, given the transactions costs associated with the supercharging process, we would not expect pre-IPO owners to supercharge an IPO unless they expect the firm to be sufficiently profitable to realize the tax benefits in the future.

${ }^{11}$ Technically, the TRA payments to pre-IPO owners in the future will generate additional step-up in basis, which will cause the pre-IPO owner to recognize additional capital gain and thus pay additional capital gains tax. This additional step-up will generate additional future tax benefits (for the IPO firm) and additional taxable gain (for the pre-IPO owner), and so forth, in perpetuity. For simplicity, Columns (3) - (5) ignore this iterative process and only incorporate the future tax benefits from the pre-IPO owner's sale of their ownership interest on the date of IPO. Calculations incorporating this iterative process are available from the authors upon request.
} 
present value of total tax costs [row (8)] for the pre-IPO owner related to the supercharged IPO is $\$ 18.09$ [ $=15$ percent of $(\$ 100+\$ 20.59)]$. Row (9) indicates the net value of the supercharged IPO for pre-IPO owners is $\$ 102.50(=\$ 100+\$ 20.59-\$ 18.09)$, which is higher than the net value in the "No IPO" scenario [\$100 in Column (1)] or the traditional IPO [\$85 in Column (2)]. In addition, the supercharged IPO in Column (3) creates higher net value for new IPO investors (\$3.63) than a traditional IPO [\$0 in Column (2)]. Thus, assuming a \$100 IPO price, full realization of future tax benefits, and tax benefit-splitting, both parties are better off by supercharging.

Columns (4) and (5) relax some of our prior assumptions and present IPO pricing for two indifference points. Column (4) assumes new investors are willing to pay the IPO price that makes them indifferent between the traditional and supercharged IPO transaction structures, again assuming all tax benefits are realized in the future. We now assume the new investors are willing to pay more than $\$ 100$ because they recognize that the supercharged IPO structure generates future tax benefits and increases firm value. Specifically, they are willing to pay $\$ 103.77$ for all shares of the IPO firm. The amount of intangible assets recorded now equals the price paid (\$103.77), which generates future tax benefits of $\$ 36.32$ undiscounted ( $\$ 25.13$ discounted) and those benefits are still allocated 85/15 between the pre-IPO owners and the new investors. However, the higher offer price of $\$ 103.77$ leads to a higher net value to the pre-IPO owner of $\$ 106.36[=\$ 103.77+$ $\$ 21.36$ - \$18.77 in row (9)]. In contrast, the new investors are indifferent between the traditional and supercharged IPO transaction structures (i.e., net value is $\$ 0$ either way). Thus, in this scenario the pre-IPO owner is better off by $\$ 6.36(=\$ 106.36$ - \$100) compared to the "No IPO" scenario in Column (1), and by $\$ 3.86(=\$ 106.36$ - $\$ 102.50)$ compared to the supercharged IPO with shared tax benefits in Column (3). We note that Column (4) is illustrative of an indifference point; however, offer prices may be higher if supercharging provides an indication of superior future 
performance, serves as a commitment mechanism for pre-IPO owners, or is a means of shifting value from new investors.

Finally, Column (5) assumes new investors are only willing to pay the IPO price that makes the pre-IPO owner indifferent between the supercharged IPO transaction structure and the "No IPO” scenario in Column (1). We now assume the new investors are not willing to pay $\$ 100$ for the IPO shares, perhaps because they view the supercharged transaction structure as shifting value to pre-IPO owners. Specifically, the new investors are only willing to pay $\$ 97.56$ for all shares of the IPO firm. The amount of intangible assets recorded now equals the price paid of $\$ 97.56$, which generates future tax benefits of $\$ 34.15$ undiscounted ( $\$ 23.63$ discounted) that are allocated $85 / 15$ between the pre-IPO owners and the new investors. However, the lower offer price of $\$ 97.56$ makes the pre-IPO owner indifferent between the supercharged IPO transaction and the "No IPO" scenario (i.e., net value is $\$ 100$ either way). ${ }^{12}$ In contrast, the new IPO investors are better off by $\$ 5.98(=\$ 5.98-\$ 0)$ compared to the traditional IPO in Column (2), and by $\$ 2.35(=\$ 5.98-\$ 3.63)$ compared to the supercharged IPO with shared tax benefits in Column (3). In this study we investigate which assumptions about supercharged IPOs appear to hold on average. That is, are supercharged IPOs priced to split tax benefits between pre-IPO owners and new investors [as in column (3)]? Or does the supercharging process allow pre-IPO owners (or new investors) to capture relatively more of the net value generated by supercharged IPO transaction structure, as illustrated in Column (4) [Column (5)]?

There is relatively little prior academic research on supercharged IPOs. Several articles describe the technical aspects of supercharged IPOs and then argue they impose net costs (e.g.,

\footnotetext{
${ }^{12}$ We chose to make the pre-IPO owner indifferent between a supercharged IPO and "no IPO" (instead of a traditional IPO) because the net value to pre-IPO owners [row (9)] is higher for the "no IPO" scenario (\$100) than the scenario of a traditional IPO with a full divestiture of ownership (\$85). In a supercharged IPO the exchange of pass-through units for public company shares is more akin to a "no IPO" setting.
} 
Shobe 2017, 2018) or net benefits (Polsky and Rosenzweig 2016) on new IPO investors. The only study that uses archival data on supercharged IPOs is Fleischer and Staudt (2014), which provides evidence that supercharged IPOs are more common when there is a tax arbitrage opportunity and when an elite lawyer from New York is involved in the process. We examine the pricing and performance implications of supercharged IPOs relative to traditional IPOs.

\subsection{IPO Pricing and Underpricing}

Prior research provides evidence that IPO firms use lock-up provisions, which restrict preIPO firm owners from selling stock for a period of time after the IPO, as a commitment mechanism between pre-IPO owners and the new public firm. Brav and Gompers (2003) argue that longer lock-up periods reduce moral hazard problems by allowing new investors to gather more information about IPO firm value via SEC filings, news stories, and analyst reports in the postIPO period (but prior to stock sales by pre-IPO firm insiders). Supercharged IPOs do not necessarily affect the ability of insiders to buy or sell shares post-IPO; however, it does bind them to the future performance of the firm. Without sufficient taxable income, the firm will not realize the deferred tax benefits related to step-up in asset basis and thus, will not make payments to preIPO owners under the tax receivable agreement. In effect, tax receivable agreements act as alternative commitment mechanisms between pre-IPO owners and the firm. Thus, similar to lockup provisions, tax receivable agreements should alleviate moral hazard problems by more closely aligning the interests of pre-IPO owners and new IPO investors.

If new IPO investors recognize the decision to supercharge an IPO as an alternative commitment mechanism that is associated with superior future performance, then supercharging should reduce information asymmetry between new IPO investors and the firm. In this case, we would expect higher offer prices and less underpricing (on the first day of trading) for supercharged 
IPOs as compared to traditional IPOs. However, if new IPO investors do not distinguish between supercharged and traditional IPOs then we would expect no differences in offer pricing between the two transaction types, which leads to the following hypotheses (stated in the alternative):

H1A: The IPO offer price is higher for supercharged IPO firms than for traditional IPO firms.

H1B: The amount of IPO underpricing (on the first day of trading) is lower for supercharged IPO firms than for traditional IPO firms.

Prior research documents only a modest association between accounting information and IPO pricing (e.g., Kim and Ritter 1999). In addition to the information and commitment mechanism theories described above, TRAs could reduce information asymmetry between preIPO owners and new IPO investors in at least two ways. First, by stripping future tax benefits from the IPO firm, tax receivable agreements eliminate assets that are often deeply discounted by new IPO investors (e.g., Bilsky and Goodman 2015). Second, IPO firms are required to disclose in Form S-1 additional information about the tax receivable agreements that underlie supercharged IPOs, which could further reduce information asymmetry and influence IPO pricing. Alternatively, critics argue Form S-1 disclosures are so complex they actually increase information asymmetry. For example, one news article describes supercharged IPOs as involving obscure tax strategies that investors do not understand. ${ }^{13}$ Thus, it is not clear a priori whether the Form S-1 disclosures are helpful or harmful to information processing by new IPO investors.

We reviewed all Form S-1 disclosures for our sample of supercharged IPOs and found the disclosures of TRAs related to the step-up in tax basis to be highly inconsistent. Some firms state that future payments under such agreements are not estimable, others provide a range for expected payments, and others disclose in pro forma financial statements the present value of expected TRA

\footnotetext{
13 "Squeezing Out Cash Long after the IPO"; Browning, New York Times, March 13, 2013.
} 
payments. Based on our review of the Form S-1s, it is not clear investors would find the disclosures informative. It is plausible the negative press regarding supercharged IPOs, combined with concerns of increased information asymmetry, could cause investors to pay less for shares of the new public company (or not purchase shares at all), potentially leading to lower offer prices for supercharged IPOs, relative to traditional IPOs.

\subsection{Future Firm Performance}

Prior studies that examine post-IPO performance generally document poor accounting and stock price performance following IPO and have provided various explanations for these findings (e.g., Ritter 1991; Jain and Kini 1994; Loughran and Ritter 1995; Mikkelson, Partch, and Shah 1997). We motivate H1A and H1B by arguing that supercharging an IPO reduces the level of information asymmetry between pre-IPO owners and new IPO investors and potentially provides an (unintentional) ex ante indication to new IPO investors of pre-IPO owners expectations for the future prospects of the firm. Recall that in supercharged transactions, pre-IPO owners are only better off (as compared to traditional IPOs) if the future tax benefits related to step-up in asset basis are realized (i.e., if future taxable income is larger than the future tax deductions generated by step-up). Thus, for pre-IPO owners to be willing to incur the additional costs of supercharging (e.g., the tax costs triggered by step-up), they must have relatively high expectations (based on their private information) for future firm performance. In this case, we should observe that the realized post-IPO performance of firms that supercharge is superior to the post-IPO performance of firms that undergo traditional IPOs.

Alternatively, as argued by critics of supercharged IPOs, TRAs could merely be one method of transferring IPO firm value from new IPO investors to pre-IPO owners. Such a transfer of value could be achieved through TRAs that obfuscate information about tax and non-tax 
attributes of the IPO firm, leading to higher offer prices (consistent with H1A and H1B) but weaker future performance of supercharged IPO firms relative to traditional IPO firms. Thus, we also investigate the following hypothesis (stated in the alternative):

H2: The future performance of supercharged IPO firms is superior to the future performance of traditional IPO firms.

\section{Research Design and Sample Selection}

\subsection{Sample Selection}

Our sample selection procedures start with all U.S. firms that undergo IPOs during the period 2004 - 2015. Consistent with Fleischer and Staudt (2014), we begin our sample period in 2004 because supercharged IPOs gained popularity in the mid-2000s. We obtain our initial sample of IPO observations from the SDC Platinum database. We require annual financial statement data from the Compustat North America database; as such, all observations must report a ticker in SDC and Compustat to match firms in both databases. To identify firms that supercharge their IPO, we use the Lexis Nexus Knowledge Mosaic Database to identify firms that refer to a "tax receivable agreement" in their Form S-1/S-1A filings with the Securities and Exchange Commission (SEC). We review all Form S-1/S-1A filings to confirm the tax receivable agreement requires payments to pre-IPO owners for tax benefits associated with a step-up in asset basis either at the time of IPO or in future share exchanges. We require all observations to report total assets for the fiscal year ending immediately before and immediately after the IPO. We also require sample firms to report basic financial data including leverage, pre-tax income, net deferred tax assets, intangibles, and goodwill for the fiscal year immediately prior to the IPO. Lastly, we require that all observations report the offer price, total proceeds, shares, and gross spread for the IPO transaction. These requirements generate a primary sample of 1,161 (50) traditional (supercharged) IPO firms.

Our sample includes at least one supercharged IPO transaction for each year of our sample 
period, except 2008. Consistent with supercharged transactions becoming more common in recent years, the number of supercharged IPOs increases throughout the sample period. Figure 3 plots of the number of traditional and supercharged IPO transactions for each year of our sample. We note that the plots for both types of IPOs follow the same pattern except in the early years of our sample.

\subsection{Initial Pricing of Supercharged IPOs}

To test our first hypothesis, which evaluates the extent to which there is differential pricing of supercharged and traditional IPOs, we estimate the following OLS regression model:

$$
\begin{aligned}
& \text { OFFER_PRICE }=\beta_{0}+\beta_{1} S C I P O+\beta_{2} S A L E S P S_{P R E}+\beta_{3} B V P S_{P R E}+\beta_{4} E P S_{P R E}+ \\
& \beta_{5} S P R E A D+\beta_{6} \text { PROCEEDS }+\beta_{7} \% \text { SHARES }+\beta_{8} V W_{-} \text {RETURN }+\beta_{9} I P O T O T+ \\
& \beta_{10} I P O R E T+\beta_{11} V C_{-} B A C K E D+\beta_{12} P E_{-} B A C K E D+\beta_{13} B I G N+\beta_{14} B I G L A W \\
&+\beta_{15} \text { RANK_UNDERWRITER }+\varepsilon
\end{aligned}
$$

We use a pooled sample of traditional and supercharged IPOs to estimate equation (1); thus, our analyses provide evidence on the differential pricing of supercharged IPOs relative to the population of traditional IPOs during the time period studied. ${ }^{14}$ The dependent variable, OFFER_PRICE, is the natural log of the final offer price immediately prior to the IPO. The primary variable of interest is the supercharged IPO indicator variable $(S C I P O)$. Consistent with the decision to supercharge an IPO being indicative of pre-IPO owners' expectations for greater future financial performance and/or serving as a commitment mechanism that leads to higher offer prices, we expect a positive and significant coefficient on SCIPO.

\footnotetext{
${ }^{14}$ In supplemental analyses we estimate equation (1) using an entropy balanced sample of traditional and supercharged IPO firms. Our results are qualitatively similar, if not stronger, based on the entropy-balanced samples. We do not use the entropy balanced samples in our primary analyses because a critical determinant of supercharging an IPO is the pre-IPO firm's organizational structure. Based on Form S-1 filings, 100 (23.8) percent of the supercharged (traditional) pre-IPO firms are pass-through entities. Because all supercharged IPOs are pass-through entities, we cannot (for econometric reasons) include a pass-through indicator variable in the entropy balancing model. Thus, we consider our entropy balancing procedure as providing corroborating but ancillary evidence to our primary analyses.
} 
We rely primarily on the IPO offer price model in Li, Lin, and Robinson (2016) and the underpricing literature to identify control variables to include in equation (1). We also include controls for firm characteristics measured as of the fiscal year ending immediately prior to the public offering, scaled by the number of shares outstanding, where appropriate. Following Loughran and Ritter (2004), we control for firm sales (SALES $\left.S_{P R E}\right)$ and firm size measured as book value per share ( $\left.B V P S_{P R E}\right)$, which they note controls for a firm's risk composition. Consistent with Li et al. (2016) and Purnanandam and Swaminathan (2004), we control for earnings per share $\left(E P S_{\text {pre }}\right)$ because earnings are an important determinant of share price. In addition, we include controls for: (1) characteristics of the IPO, including total IPO fees, a.k.a., "gross spread" (SPREAD), total IPO proceeds (PROCEEDS), and the percentage of shares sold at IPO (\%SHARES), e.g., Cliff and Denis (2004), Lowry and Murphy (2007), Li et al. (2016); (2) valueweighted market returns for the two months prior to IPO (VW_RETURN), e.g., Lowry (2003), Li et al. (2016); (3) momentum in the IPO market, including the total number of IPOs in the two calendar months preceding the IPO (IPOTOT) and the average initial day stock return for all IPOs in the two calendar months preceding the IPO (IPORET), e.g., Lowry (2003) and Li et al. (2016); (4) historic ownership of the IPO firm with indicator variables for whether the firm is backed by venture capital (VC_BACKED) or private equity (PE_BACKED), e.g., Loughran and Ritter (2004), Li et al. (2016); (5) the use of a large law firm (BIGLAW) or Big 4 accounting firm (BIGN); e.g., Fleisher and Staudt (2014), Li et al. (2016); and (6) quality of the lead underwriter (RANK_UNDERWRITER), e.g., Loughran and Ritter (2004).

We estimate two specifications of equation (1), both of which include industry and year fixed effects and robust standard errors. In addition to the primary specification above, we estimate 
a model that includes deferred tax assets, $D T A P S_{P R E}$, as a proxy for tax exhaustion and because investors have difficulty valuing deferred tax assets (e.g., Bilsky and Goodman 2015).

\subsection{Underpricing of Supercharged IPOs}

In addition to examining initial offer prices of supercharged vs. traditional IPOs (H1A), we also investigate the amount of IPO underpricing on the first day of trading for supercharged IPOs relative to traditional IPOs (H1B). We estimate equation (1) as shown above, but we replace the dependent variable with UNDERPRICING, measured as the percentage change in offer price on the first day of trading. In addition to the control variables included in equation (1), we also control for the offer price just before IPO (OFFER_PRICE), as the amount of underpricing should be a function of the offer price. We estimate two specifications of the UNDERPRICING regressions, both of which include industry and year fixed effects and robust standard errors. The first (second) estimation does (does not) include the amount of deferred tax assets before the IPO (DTAPS PRE).

\subsection{Future Performance of Firms that Supercharge IPOs}

Next, we examine $\mathrm{H} 2$ and test whether there is differential future performance between supercharged and traditional IPO firms based on the following regression model:

$$
\text { FUT_PERFORM }=\beta_{0}+\beta_{1} S C I P O+\beta_{2} L A G_{-} P E R F O R M+\beta_{3} S I Z E_{P R E}+\varepsilon
$$

where future firm performance (FUT_PERFORM) is measured for the fiscal year that follows the IPO. We measure firm performance with three different proxies, including earnings before interest and taxes (EBIT $\left.T_{P O S T}\right)$, sales (SALESPOST), and cash flows from operations (CFOPOST), all scaled by total assets. Consistent with prior research on post-IPO performance we use a relatively parsimonious model that includes controls for firm size and lagged performance (e.g., Jain and Kini 1994; Mikkelson, Partch, and Shah 1997). Specifically, Equation (2) includes the performance variable measured for the fiscal year prior to IPO (LAG_PERFORM), which controls 
for serial correlation in firm performance. We also control for firm size at fiscal year-end prior to IPO [total assets $\left.\left(S I Z E_{P R E}\right)\right]$, in case future performance varies systematically with firm size. We estimate equation (2) with year and industry fixed effects and robust standard errors.

In supplemental analyses, we examine cumulative stock returns in the post-IPO period. In these tests, the dependent variables are the percentage change in share price measured shortly (i.e., two months) after IPO and one year following the IPO. These variables are regressed on the supercharged IPO indicator variable (SCIPO) and the three Fama and French (1993) risk factors [i.e., the excess return on the market (MKT), the average return on small minus big firm portfolios $(S M B)$, and the average return on high minus low book-to-market portfolios $(H M L)]$. If the post IPO returns of supercharged IPOs are similar to those of traditional IPOs, the coefficients on SCIPO will not be significant. All variables, for all equations, are defined in Appendix A.

\section{Results \& Analysis}

\subsection{Descriptive Information about Traditional and Supercharged IPO Firms}

Table 1 presents descriptive statistics for our sample of traditional and supercharged IPOs. Providing univariate support for H1A, supercharged IPOs exhibit significantly higher mean offer prices (mean OFFER_PRICE of 2.92 for supercharged IPOs vs. 2.59 for traditional IPOs, p-value $<0.01$; the pre-logarithm values are 18.45 and 13.29 , respectively). Consistent with H1B, supercharged IPOs exhibit less underpricing, although not at conventional significance levels (mean UNDERPRICING of 0.09 for supercharged IPOs versus 0.14 for traditional IPOs). Consistent with H2, supercharged IPOs exhibit greater future performance as measured by earnings before interest and taxes (mean $E B I T_{P O S T}$ of 0.139 for supercharged IPOs versus -0.076 for traditional IPOs, p-value $<0.01$ ) and cash flow from operations (mean $C F O_{P O S T}$ of 0.106 for supercharged IPOs versus -0.093 for traditional IPOs, $p$-value $<0.01$ ). Additionally, supercharged 
IPOs exhibit higher sales, although not at conventional significance levels, (mean SALES POST of 0.982 for supercharged IPOs versus 0.825 for traditional IPOs). Many of the control variables are also significantly different between the two types of IPO firms. Supercharged IPO firms are larger (SIZE $\left.E_{P R E}\right)$, more profitable $\left(P T I_{P R E}\right)$, and have higher pre-IPO sales $\left(S A L E P S_{P R E}\right)$.

Table 2 presents detailed information on the amounts of expected and realized tax benefits disclosed by supercharged IPO firms in their Form S-1 filings. As pre-IPO owners exchange passthrough ownership units for shares of the new public company (at the time of IPO or after), the firm's assets are stepped-up to fair market value. This step-up generates larger future tax deductions (and thus, larger cash flows) for the firm, which are shared with pre-IPO owners as they are realized. Because the exchanges that trigger step-up can occur at IPO and/or at future dates, disclosures about these tax benefits in Form S-1 filings vary greatly across firms. For our sample of 50 supercharged IPO firms, Table 2 presents the amount of tax benefits recognized in pro forma financial statements at the time of IPO and the disclosed amount of anticipated total tax benefits, assuming all pass-through ownership units are exchanged post-IPO. Our understanding is that the amounts reported in pro forma financial statements have greater certainty than those disclosed in the text of Form S-1/S-1A. Additionally, we reviewed the Form 10-K filings for the three years following IPO (where data is available) and report the actual payments to pre-IPO owners made pursuant to the tax receivable agreement. We note that three years of data is fairly limited, as the future tax benefits are likely realized over many years (e.g., goodwill is amortized over 15 years for federal tax purposes). Thus, we expect the actual payments to capture only a small proportion of the deferred tax assets recognized or disclosed.

Table 2 highlights the magnitudes of the tax benefits generated by supercharged IPOs relative to a firm's enterprise value and the IPO offer price. For example, in row (37) the Planet 
Fitness IPO generated anticipated total tax benefits (see columns 6 and 7 ) of $\$ 843.3$ million ( $\$ 8.54$ per share), \$137.6 million (\$1.39 per share) of which were recorded in pro forma financial statements at the time of IPO (see columns 4 and 5). The firm's enterprise value post-IPO was $\$ 1,018.4$ million and its IPO price was $\$ 16$ per share. ${ }^{15}$ Thus, the anticipated (recorded) tax benefits constitute 82.8 (13.5) percent of the firm's enterprise value post-IPO and 53.4 (8.7) percent of the firm's IPO price. These amounts are clearly material to the firm.

More generally, the mean amount of anticipated (recorded) tax benefits for our sample of 50 supercharged IPOs is $\$ 485.72$ ( $\$ 183.89$ ) million, which constitutes 29 (11) percent of post-IPO enterprise value, on average. On a per share basis, the average anticipated (recorded) tax benefits constitute 67.1 (23.7) percent of the mean IPO price of $\$ 19.35$. However, the average supercharged IPO firm paid only $\$ 11$ million ( $\$ 0.23$ per share) to pre-IPO owners in the three years following IPO. Despite these relatively small amounts of actual payments to pre-IPO owners post-IPO, the Form S-1s indicate supercharged IPO firms expect to generate substantial tax benefits in the future, which will increase the cash flows for both the pre-IPO owners and the new public company.

Table 3 presents the industry composition of traditional and supercharged IPO firms, based on the Fama-French 48 industry classification scheme and the Fama-French 5 industry classification scheme. ${ }^{16}$ Given our small sample size, we utilize the Fama-French 5 industry classification for equations (1) and (2); however, we also provide descriptive details based on the Fama-French 48 industry classification. We note the higher concentrations of supercharged IPOs in the entertainment, coal, petroleum \& natural gas, real estate, and trading sectors in Panel A.

\footnotetext{
${ }^{15}$ We define enterprise value as the number of shares outstanding multiplied by the closing stock price plus debt less cash, all measured on the last day of the fiscal year following IPO.

${ }^{16} \mathrm{See}$ http://mba.tuck.dartmouth.edu/pages/faculty/ken.french/Data_Library/det 48 ind_port.html and http://mba.tuck.dartmouth.edu/pages/faculty/ken.french/Data_Library/det_5 ind_port.html for the industry classifications.
} 
Table 4 presents Pearson correlations among the primary variables of interest. Consistent with $\mathrm{H} 1 \mathrm{~A}$, the supercharged IPO indicator variable, SCIPO, is positively correlated with the initial pricing of the IPO, OFFER_PRICE $(\rho=0.148)$. In contrast, SCIPO is not significantly correlated with the amount of IPO underpricing on the first day of trading (UNDERPRICING). With respect to the association (if any) between supercharged IPOs and future firm performance, the results in Table 4 indicate that $S C I P O$ is positively correlated with $E B I T_{P O S T}$ and $C F O_{P O S T}$, as predicted under $\mathrm{H} 2$. Thus, preliminary evidence suggests the tax receivable agreements that underlie supercharged IPOs are indicative of pre-IPO owners' expectations of superior future performance.

\subsection{Multivariate Analyses of the Pricing of Traditional and Supercharged IPOs}

Column (1) of Table 5 presents the results for OLS estimations of equation (1), which examines the offer prices of traditional and supercharged IPOs (SCIPO). If the TRAs that underlie supercharged IPOs are indicative of superior future performance or create commitment mechanisms between firms and pre-IPO owners such that new IPO investors are willing to pay higher IPO prices, then we expect the coefficient on $S C I P O$ to be positive and significant. In support of H1A, we observe a significant positive coefficient on SCIPO (coefficient of 0.153, pvalue $<0.01)$. This coefficient indicates that supercharged IPOs have offer prices that are on average 17 percent higher than those for traditional IPOs [i.e., $\exp (0.153)=1.17$ ].

In addition to the baseline model presented in column (1), we estimate an additional specification of equation (1) that includes net deferred tax assets measured just before IPO $\left(D T A P S_{P R E}\right)$. Recall that $D T A P S_{P R E}$ controls for this difficult-to-value asset and also proxies for tax exhaustion (i.e., history of losses). After the inclusion of DTAPS $P R E$ in the model, inferences

from Table 5, column (1) continue to hold as the coefficient on SCIPO remains positive and 
significant (coefficient of 0.151 , p-value $<0.01$ ). Overall, these results are consistent with supercharged IPO firms issuing stock at higher offer prices than traditional IPO firms.

Supercharged IPOs could have higher offer prices than traditional IPOs for several different reasons. Investors could be willing to pay more simply to obtain the future tax benefits generated by the step-up in asset basis, and/or because they expect supercharged IPO firms to have superior future performance, or because new investors are somehow "deceived" and pay higher prices. To shed light on these issues, we calculate the amount of future tax benefits from step-up that are allocated to the firm (and thus, to new IPO investors) and compare this amount to the incremental offer price the new IPO investors are willing to pay for supercharged IPOs. To the extent the new IPO investors are willing to pay an incrementally higher IPO price that exceeds the amount of tax savings retained by the firm, our results are consistent with new investors anticipating superior future performance or with them overpaying for the IPO shares.

We base our calculations on amounts presented in Table 2. We first use the amount of deferred tax assets recognized by 28 supercharged IPO firms in the pro forma financial statements included in their Form S-1 filings, as these amounts have a higher degree of certainty with respect to future realization. For these firms the mean (median) undiscounted value of tax benefits generated by the step-up in tax basis attributable to new IPO investors is $\$ 0.69(\$ 0.37)$ per share. ${ }^{17}$ We now compare these amounts to the estimated incremental offer price of $\$ 2.20$ per share paid on average by new IPO investors for supercharged IPO firms. ${ }^{18}$ Both the mean and median amounts of estimated tax benefits from step-up are less than the estimated incremental offer price

\footnotetext{
${ }^{17}$ We calculate the mean value of $\$ 0.69$ "attributable to new IPO investors" by multiplying the mean per share amount shown in the last row of Table 2, column 2 (\$4.58) by 15 percent, i.e., the proportion of tax benefits typically retained by the new public company.

${ }^{18}$ The incremental offer price is calculated as [(Euler's number to the power of the coefficient on SCIPO in column (1) of Table 5 minus 1$) \times$ mean offer price for traditional IPOs $]=\left(\mathrm{e}^{\wedge} 0.153-1\right) \times \$ 13.29=\$ 2.20$.
} 
per share. Additionally, when examining the estimates on a firm-by-firm basis, the incremental offer price is greater than the undiscounted tax benefits from step-up for 27 of the 28 disclosing firms (results untabulated). These results provide preliminary evidence new IPO investors pay an incrementally higher IPO price that is larger than their share of future tax benefits.

We now use the amount of anticipated total increase in deferred tax assets to occur at IPO and/or in future exchanges, as disclosed in Form S-1 filings by 25 supercharged IPO firms. The mean (median) undiscounted total amount of anticipated tax benefits generated by the step-up in tax basis attributable to new IPO investors is $\$ 1.95(\$ 1.09)$ per share. ${ }^{19}$ Again, the mean and median amount of tax benefits attributable to new IPO investors are less than the incremental offer price of $\$ 2.20$ per share. On a firm-by-firm basis the anticipated future tax benefits are less than the incremental offer price for 20 of the 25 firms disclosing this information. Although these estimates of anticipated tax benefits are almost certainly too high (i.e., all of the future tax benefits would need to be realized immediately), these comparisons consistently indicate the incremental offer price for supercharged IPO firms is higher than the tax benefits attributable to new IPO investors. These results are consistent with new investors anticipating superior future performance or with them overpaying for the IPO shares, possibilities that we investigate in tests of $\mathrm{H} 2$.

Column (1) of Table 6 presents results for estimations of equation (2), which examines the underpricing of traditional and supercharged IPOs (SCIPO). If the TRAs that underlie supercharged IPOs are indicative of superior future performance or create commitment mechanisms between firms and pre-IPO owners, then we expect the coefficient on SCIPO to be negative and significant. This result would be consistent with lower information asymmetry and thus less IPO underpricing for supercharged IPO firms as compared to traditional IPO firms. In

\footnotetext{
${ }^{19}$ We calculate the mean value of $\$ 2.51$ "attributable to new IPO investors" by multiplying the mean per share amount shown in the last row of Table 2, column $1(\$ 12.99)$ by 15 percent. The median value is $\$ 7.25$.
} 
column (1) we fail to find support for $\mathrm{H} 1 \mathrm{~B}$, as the coefficient on SCIPO is not statistically different from zero. In column (2) we add our proxy for the potential step-up in asset basis, DTAPS pre and continue to observe an insignificant coefficient on SCIPO.

Taken together the results in Tables 5 and 6 are consistent with supercharged IPO firms issuing stock with higher offer prices than traditional IPO firms but not experiencing a significant difference in IPO underpricing on the first day of trading. Although we find similar underpricing on the first day of trading (H1B), the evidence of higher offer prices prior to trading (H1A) is nonetheless consistent with our prediction that supercharging an IPO provides an indication to the market about the firm's future prospects and creates a commitment mechanism between pre-IPO owners and the firm. We now discuss our findings for tests of $\mathrm{H} 2$.

\subsection{Future Performance of Traditional and Supercharged IPO Firms}

Table 7 presents results for estimations of equation (3), which compares the future performance of supercharged and traditional IPO firms. H2 predicts that supercharged IPO firms exhibit superior future performance relative to traditional IPO firms. Column (1) examines the future performance of IPO firms, as measured by earnings before interest and taxes (EBITPOST). Consistent with $\mathrm{H} 2$, we observe higher future earnings for supercharged IPO firms as compared to traditional IPO firms. The coefficient on SCIPO is positive and significant (coefficient $=0.066$ ). Column (2) compares the future performance of supercharged and traditional IPO firms as measured by sales, SALES POST. We observe higher future sales for supercharged IPO firms; however, the coefficient on $S C I P O$ is not significant at conventional levels (coefficient $=0.149$ ). Column (3) compares the future performance of supercharged and traditional IPO firms as measured by cash flow from operations, $C F O_{P O S T}$. Again, we observe higher future operating cash flows for supercharged IPO firms; however, the coefficient on SCIPO is not significant at 
conventional levels (coefficient of 0.053). Overall, the results provide weak evidence that supercharged IPO firms exhibit superior future performance (relative to traditional IPO firms).

\section{Supplemental Analyses}

In this section, we perform a number of supplemental analyses to provide additional insights into supercharged IPOs. First, we examine the future stock performance of supercharged and traditional IPOs. We then examine the impact of alternative commitment mechanisms between IPO firms and pre-IPO owners: restricted stock and lockup provisions. Lastly, we repeat our primary analyses using an entropy-balanced sample.

\subsection{Future Stock Performance of Traditional and Supercharged IPOs}

We compare the future stock performance of supercharged and traditional IPO firms as an alternative measure of future performance. Since we document higher offer prices for firms that supercharge their IPOs, documenting lower future stock returns for supercharging firms would be consistent with supercharging merely serving as a means of rent extraction by pre-IPO owners (i.e., artificially high offer prices for supercharged IPO firms that eventually decline compared to traditional IPO firms, following IPO). Alternatively, higher future stock returns for supercharged IPO firms would be consistent with supercharging providing an indication of superior future performance that is not fully incorporated into offer prices (i.e., superior firm performance is revealed and then incorporated into stock price through time, resulting in higher future returns). In contrast, similar future stock returns for supercharged and traditional IPO firms would be consistent with the higher offer price for supercharged IPOs being appropriate (i.e., supercharged IPOs are not more overpriced or underpriced than traditional IPO firms over a longer time period).

Table 8 presents results from tests that regress two-month and one-year stock returns on the supercharged IPO indicator and control variables. In these analyses, we only include firms that 
report stock returns in CRSP one year following the IPO. We include the three Fama-French factors $(M K T, S M B$, and $H M L)$ and industry and year fixed effects in our regressions. Consistent with the third scenario described above, we find that supercharged IPO firms experience twomonth and one-year stock returns that are not statistically different from those of traditional IPO firms. Thus, we cautiously conclude the higher offer prices for supercharged IPO firms are appropriate, on average.

\subsection{SCIPOs as a Commitment Mechanism}

Our analyses provide evidence consistent with supercharged IPOs having higher offer prices than traditional IPOs, a phenomenon potentially driven by several different factors. In this section, we consider one specific factor that could explain the higher offer prices for supercharged IPO firms. Specifically, we examine whether the TRAs that underlie supercharged IPOs act as a commitment mechanism between pre-IPO owners and the firm. Frequently used in traditional IPOs, lockup provisions restrict managers and pre-IPO owners from selling their shares for a period of time following the IPO. As a result, they function as a commitment device that alleviates moral hazard problems by aligning insiders' incentives with those of new IPO investors (Brav and Gompers 2003). If the TRAs that underlie supercharged IPOs act as an alternative commitment mechanism (instead of lockup provisions), our hypothesized positive relation between supercharged IPOs and offer prices should be strongest in firms with fewer shares subject to lockup (or other sales restrictions) at the time of IPO because the TRAs that underlie supercharged IPOs should have a larger impact on the moral hazard problem at these firms.

To test this prediction, we create an indicator variable, $L O C K U P$, that equals one for IPO firms whose percentage of pre-IPO shares that are subject to lockup provisions are above the sample mean, and zero otherwise. In this test, we classify IPO firm shares as "locked-up" if they 
are designated as locked-up or otherwise restricted in the Form S-1 or S-1/A immediately prior to the IPO. We add LOCKUP and its interaction with SCIPO to equation (1) and repeat our analyses. If the TRAs that underlie supercharged IPOs act as alternative commitment mechanisms, then we expect the coefficient on $S C I P O(S C I P O \times L O C K U P)$ to be positive (negative) and significant.

Table 9 presents the results from these supplemental tests. Column (1) includes the base specification. As predicted we observe a positive and significant coefficient on SCIPO (coefficient of 0.217 , p-value $<0.01$ ), consistent with supercharged IPO firms with relatively small proportions of pre-IPO shares subject to lockup having higher offer prices than traditional IPO firms. In contrast, the coefficient on $S C I P O \times L O C K U P$ is negative (coefficient of -0.157 , p-value $<0.10$ ) and an F-test indicates the sum of the coefficients on SCIPO and SCIPO $\times L O C K U P$ is not statistically different from zero. These results are consistent with the higher offer prices of supercharged IPO firms being attenuated for firms with relatively high percentages of pre-IPO shares subject to lockup provisions. Column (2) of Table 9 adds the control variable for deferred tax assets to the regression model. Inferences from this specification are unchanged. In sum, these results suggest the TRAs that underlie supercharged IPOs act as alternative commitment mechanisms and reduce agency problems at supercharged IPO firms.

\subsection{Entropy Balanced Sample}

Our primary analyses are based on a pooled, un-balanced sample to provide evidence on the pricing and performance of supercharged IPOs compared to the full sample of traditional IPOs. It is possible that innate firm characteristics associated with a firm's decision to supercharge are also related to the differential IPO pricing and future performance of traditional and supercharged IPO firms. In this case, selection bias could generate biased regression estimates. To address this econometric concern, we repeat our primary analyses using an entropy balanced sample. Entropy 
balancing reweights the observations in the control sample such that the control sample data more closely resembles the treatment sample data. This reweighting reduces the impact of observable characteristics on the treatment variable (i.e., SCIPO), reducing concerns that differences in subsequent treatment effects (e.g., IPO pricing) are a function of the observable characteristics rather than the treatment variable, SCIPO (Hainmueller and Xu 2013). ${ }^{20}$

We balance our treatment (i.e., supercharged IPO firms) and control (i.e., traditional IPO firms) observations on all statistically significant variables in the following determinates model:

$$
\begin{aligned}
& S C I P O=\beta_{0}+\beta_{1} S_{I Z E_{P R E}}+\beta_{2} P_{T I I_{P R E}}+\beta_{3} L_{E} V_{P R E}+\beta_{4} N_{N e t D T A} A_{P R E}+\beta_{5} I_{N T A N G I B L E S} S_{P R E} \\
& +\beta_{6} V C_{-} B A C K E D+\beta_{7} P E_{-} B A C K E D+\beta_{8} B I G N+\beta_{9} B I G L A W+ \\
& \beta_{10} R A N K \_U N D E R W R I T E R+\varepsilon
\end{aligned}
$$

The independent variables include factors that likely influence the decision to engage in a supercharged IPO, including proxies for pre-IPO firm size, profitability, and financing sources, and the presence of expert legal counsel, accountants, and underwriters. Detailed variable descriptions are provided in Appendix A.

As reported in Table 10, we find that firms engaging in supercharged IPOs are larger, more highly levered firms, with greater net deferred tax assets, suggesting a potential for tax exhaustion. They are less likely to have venture capital backing and more like to employ an elite law firm for the IPO. We use these findings to entropy-balance our treatment and control samples based on $S I Z E_{P R E}, L E V_{P R E}, N e t D T A_{P R E}, V C \_B A C K E D$, and BIGLAW. We then re-estimate equations (1)-(3)

\footnotetext{
${ }^{20}$ Similar to the more familiar propensity score matching (Rosenbaum and Rubin 1983), the goal of entropy balancing is to achieve a control sample that mirrors the treatment sample on observable covariates (Hainmueller 2011). With entropy balancing the algorithm identifies weights for the observations in the control group that create a "balanced" sample on the selected observable covariates (McMullin 2018). The benefits of entropy balancing include: 1) entropy balancing does not limit the control sample to be a one-to-one (or one-to-multiple) observation match but instead uses a greater number of control firm observations with appropriate weighting to achieve sample balance (McMullin and Schonberger 2018); 2) entropy balancing generates less approximation error (Hainmueller 2011); and 3) while misspecified propensity scores can lead to bias for subsequent analysis of the treatment effect (Diamond and Sekhon 2013), an entropy balanced sample is no worse than that of an unmatched sample (Hainmueller 2011).
} 
based on the balanced samples of supercharged and traditional IPO firms. The summary of results presented in Panels B-D of Table 10 are largely consistent with those shown in Tables 5-7; however, the results in Panel D provide more compelling evidence that supercharged IPO firms exhibit superior future earnings and cash flows than similar traditional IPO firms.

\section{Conclusion}

This study examines the tax benefits generated by, and the pricing and future performance implications of, a new IPO transaction structure, which we refer to as "supercharged" IPOs. This IPO structure involves a series of transactions where a firm, organized as a pass-through entity before IPO, steps-up its tax basis in assets, thereby creating future tax benefits for pre-IPO owners and new IPO investors. Critics have argued that supercharged IPOs, and the corresponding tax receivable agreements, allow pre-IPO owners to take advantage of uninformed investors and essentially shift IPO firm value back to pre-IPO owners. We examine the credibility of these accusations by comparing the offer prices, underpricing on the first day of trading, and the future performance of traditional and supercharged IPO firms.

Because pre-IPO owners only benefit from tax receivable agreements as tax benefits are realized in the future, we contend the TRAs that underlie supercharged IPOs could be indicative of pre-IPO owners' expectations for the future prospects of the firm. If new investors price this information or value the TRA as a commitment mechanism that reduces moral hazard problems, offer prices will be higher for supercharged IPO firms. We provide evidence consistent with our predictions by documenting higher offer prices and superior future performance for supercharged IPO firms. Our analyses reveal the mean offer price for supercharged IPOs is approximately 17 percent (or \$2.20 per share) higher than that of traditional IPOs. We also provide evidence that supercharged IPOs report earnings before income taxes that are higher than that of traditional IPO 
firms in the post-IPO period. We interpret these results as consistent with TRAs providing information about future performance and/or incentive alignment, instead of acting as a mechanism for shifting value from new IPO investors to pre-IPO owners.

Our study makes several contributions to the academic literature. First, we contribute to the scant literature on supercharged IPOs. Prior work on this topic has been in the law literature with a focus on describing the transactions and identifying determinants (e.g., Fleischer and Staudt 2014; Shobe 2017). Using archival research methods from the accounting and finance literatures, we examine the initial pricing, underpricing, and future performance of supercharged IPOs as compared to traditional IPOs and contribute to the broader literature on traditional IPOs. We also contribute to the academic literature that examines how taxes influence asset prices and transaction structure, especially studies focusing on tax benefit-splitting (e.g., Ayers et al. 2000; Henning and Shaw 2000; Erickson and Wang 1999, 2000, 2007). Our research builds on these prior studies through an examination of tax benefit-splitting in the context of IPOs.

Our study also builds on prior research that documents the benefits of organizing new businesses as pass-through entities (e.g., see Erickson and Wang 2007 for a discussion of the benefits in the acquisition setting). Our findings indicate that organizing new businesses as passthrough entities, such as LLCs, can produce large tax benefits when part (or all) of the business is sold via IPO. These tax benefits are usually not available to businesses organized as C corporations, as the two levels of income tax to which they are subject typically generate costs that exceed the benefits of the supercharged IPO transaction structure.

In closing, we acknowledge that the Tax Cut and Jobs Act of 2017 (TCJA) reduced the corporate tax rate from 35 to 21 percent, seemingly reducing the tax benefits generated by the supercharged IPO transaction structure. Only the passage of time will reveal the full impact of 
these tax rate changes. Nonetheless, using the SDC Platinum and Lexis Nexis Knowledge Mosaic databases, we were able to document twelve transactions that either have been (seven) or are expected to be (five) executed as supercharged IPOs during 2018 (as of July 24, 2018). Thus, although the TCJA modified the cost-benefit analysis for the supercharged IPO transaction structure, Form S-1 filings during 2018 thus far indicate that firms organized as pass-through entities continue to find the supercharged IPO transaction structure an effective tool for generating and preserving future tax benefits. 


\section{REFERENCES}

Ayers, B. C., C. E. Lefanowicz, and J. R. Robinson. 2000. The Effects of Goodwill Tax Deductions on the Market for Corporate Acquisitions. Journal of the American Taxation Association, 22 Supplement, 34-50.

Bilsky, J., and A. Goodman. 2015. An Alternate Route to an IPO: The Up-C Partnership Structure. The Tax Advisor, November.

Brav, A., and P. Gompers. 2003. The Role of Lockups in Initial Public Offerings. Review of Financial Studies, 16(1): 1 -29.

Browning, L. 2013. Squeezing Out Cash Long After the IPO, New York Times, March 13, 2013.

Cliff, M. T., and David J. Denis. 2004. Do initial public offering firms purchase analyst coverage with underpricing? The Journal of Finance 59 (6): 2871-2901.

Diamond, A., and J. S. Sekhon. 2013. Genetic matching for estimating causal effects: A general multivariate matching method for achieving balance in observational studies. Review of Economics and Statistics 95.3: 932-945.

Erickson, M., and S.Wang. 1999. Exploiting and Sharing Tax Benefits: Seagram and Du Pont. Journal of American Taxation Association 21(2): 35 - 54.

Erickson, M., and S.Wang. 2000. The effect of transaction structure on price: Evidence from subsidiary sales. Journal of Accounting and Economics 30(1): 59-97.

Erickson, M., and S.Wang. 2007. Tax Benefits as a Source of Merger Premiums in Acquisitions of Private Corporations. Accounting Review 82(2): 359-387.

Fama, E. F., and K. R. French. 1993. Common Risk Factors in the Returns on Stocks and Bonds. Journal of Financial Economics 33: 3-56.

Fleischer, V., and N. Staudt. 2014. The Supercharged IPO, Vanderbilt Law Review, 67: 307-373.

Gleason, C. A., and L. F. Mills. 2002. Materiality and contingent tax liability reporting. The Accounting Review, 77(2), 317-342.

Hainmueller, J. 2011. Entropy balancing for causal effects: A multivariate reweighting method to produce balanced samples in observational studies. Political Analysis, mpr025.

Hainmueller, J., and Y. Xu. 2013. Ebalance: A Stata package for entropy balancing. Journal of Statistical Software, 54(7).

Henning, S. L. and W. H. Shaw. 2000. The effect of the tax deductibility of goodwill on purchase price allocations." Journal of the American Taxation Association 22.1: 18-37. 
Jain, B., and O. Kini. 1994. The post-issue operating performance of IPO firms, The Journal of Finance, 49 (5): 1699-1726.

Kim, M., and J. R. Ritter. 1999. Valuing IPOs, Journal of Financial Economics, 53 (3): 409-437.

Li, O. Z., Y. Lin, and J. R. Robinson. 2016. The effect of capital gains taxes on the initial pricing and underpricing of IPOs. Journal of Accounting and Economics, 61: 465-485.

Loughran, T., and J. Ritter. 1995. The New Issues Puzzle, The Journal of Finance, 50 (1): 23-51.

Loughran, T., and J. Ritter. 2004. Why has IPO underpricing changed over time? Financial Management, 33, 5-37

Lowry, M. 2003. Why does IPO volume fluctuate so much? Journal of Financial Economics 67.1 (2003): 3-40.

Lowry, M., and K. J. Murphy. 2007. "Executive stock options and IPO underpricing." Journal of Financial Economics 85.1: 39-65.

McMullin, J. L. 2018. Can I borrow your footnotes? Footnote boilerplate's learning externality. Kelley School of Business Research Paper No. 2014-13.

McMullin, J. L., and B. Schonberger. 2018. Entropy-Balanced Discretionary Accruals. Kelley School of Business Research Paper No 15-31.

Mikkelson, W., M. Partch, and K. Shah. 1997. Ownership and Operating Performance of Companies that Go Public, Journal of Financial Economics, 44 (3): 281-037.

Polsky, G., and A. Rosenzweig. 2016. The Up-C revolution. University of Georgia working paper.

Purnanandam, A. K., and B. Swaminathan. 2004. Are IPOs really underpriced? The Review of Financial Studies 17.3: 811-848.

Ritter, J. 1991. The Long-Run Performance of Initial Public Offerings, The Journal of Finance, 46(1): 3-27.

Rosenbaum, P. R., and D. B. Rubin. 1983. The central role of the propensity score in observational studies for causal effects. Biometrika 70.1: 41-55.

Sholes, M. S., M. A. Wolfson, M. M. Erickson, M. L. Hanlon, E. L. Maydew, and T. J. Shevlin. 2015. Taxes and Business Strategy. $5^{\text {th }}$ Edition. New York, NY. Pearson.

Shobe, G. 2017. Supercharged IPOs, the Up-C. University of Colorado Law Review, 88: 913. 
Shobe, G. 2018. Private Benefits in Public Offerings: Tax Receivable Agreements in IPOs. Vanderbilt Law Review, 71:3. 


\section{APPENDIX A Variable Definitions}

\begin{tabular}{|c|c|}
\hline 1 YR RETURNS & $\begin{array}{l}=\text { The percentage change in the share price during the first year following the } \\
\text { IPO. }\end{array}$ \\
\hline 2 MO RETURNS & $\begin{array}{l}=\text { The percentage change in the share price during the two months following } \\
\text { the IPO. }\end{array}$ \\
\hline$B I G L A W$ & $\begin{array}{l}=\text { Indicator variable set to } 1 \text { if the legal counsel utilized for the IPO, as } \\
\text { reported on the Form S-1 filing, holds a 3\% or greater share of the IPO } \\
\text { market during the sample period. }\end{array}$ \\
\hline$B I G N$ & $\begin{array}{l}=\text { Indicator variable set to } 1 \text { if the accounting firm including in the Form S-1 } \\
\text { filing was a "Big 4" accounting firm. }\end{array}$ \\
\hline$B V P S_{P R E}$ & $\begin{array}{l}=\text { Total Equity as of the fiscal year end prior to the IPO (AT-LT), divided by } \\
\text { total shares outstanding immediately following the IPO. }\end{array}$ \\
\hline$C F O_{P O S T}$ & $\begin{array}{l}=\text { Cash flow from operations (OANCF) for the fiscal year ending immediately } \\
\text { following the IPO, scaled by total assets. }\end{array}$ \\
\hline$D T A P S_{P R E}$ & $\begin{array}{l}=\text { Net deferred tax assets (TXNDB) as of the fiscal year end prior to the IPO, } \\
\text { divided by total shares outstanding immediately following the IPO. }\end{array}$ \\
\hline$E B I T_{P O S T}$ & $\begin{aligned}= & \text { Earnings before interest and taxes (EBIT) for the fiscal year ending } \\
& \text { immediately following the IPO, scaled by total assets. }\end{aligned}$ \\
\hline$E P S_{P R E}$ & $\begin{array}{l}=\text { Pre-tax income for the fiscal year ending prior to the IPO, divided by total } \\
\text { shares outstanding immediately following the IPO. }\end{array}$ \\
\hline INTANGIBLES $S_{P R E}$ & $\begin{array}{l}=\text { Total intangible assets (INTAN) as of the fiscal year end prior to the IPO, } \\
\text { scaled by total assets. }\end{array}$ \\
\hline IPORET & $\begin{array}{l}=\text { The average first day return on IPOs for the two calendar months prior to the } \\
\text { firm's IPO month. }\end{array}$ \\
\hline IPOTOT & $\begin{array}{l}=\text { The total number of IPOs for the two calendar months prior to the firm's } \\
\text { IPO month. }\end{array}$ \\
\hline$\# L E A D$ & $=$ The number of lead and co-lead underwriters for the IPO. \\
\hline$L E V_{P R E}$ & $\begin{array}{l}=\text { Total liabilities (LT) divided by total assets (AT) as of the fiscal year end } \\
\text { prior to the IPO. }\end{array}$ \\
\hline$L O C K U P$ & $\begin{array}{l}=\text { Indicator variable set to } 1 \text { if the percentage of total shares locked-up or } \\
\text { restricted is greater than the sample mean of } 70 \% \text {. }\end{array}$ \\
\hline NetDTA $A_{P R E}$ & $\begin{array}{l}=\text { Net deferred tax assets (TXNDB) as of the fiscal year end prior to the IPO, } \\
\text { scaled by total assets. }\end{array}$ \\
\hline OFFER_PRICE & $=$ The log of the final offer price per share for the initial public offering. \\
\hline$P E \_B A C K E D$ & $=$ Indicator variable set to 1 if a pre-IPO owner was a private equity firm. \\
\hline PROCEEDS & $\begin{array}{l}=\text { The total proceeds from the IPO, scaled by total assets as of the fiscal year } \\
\text { end prior to the IPO. }\end{array}$ \\
\hline$P T I_{P R E}$ & $\begin{array}{l}=\text { Pre-tax income for the fiscal year ending prior to the IPO, scaled by total } \\
\text { assets. }\end{array}$ \\
\hline
\end{tabular}




\begin{tabular}{|c|c|}
\hline RANK_UNDERWRITER & $\begin{array}{l}=\text { Underwriter rankings are based on the order in which firms are listed in the } \\
\text { underwriting section of the prospectus, on a scale of 0-9 with } 9 \text { being } \\
\text { assigned to underwriters appearing first (Loughran and Ritter 2004). } \\
\text { Underwriter rankings were obtained from Jay Ritter's website } \\
\text { (https://site.warrington.ufl.edu/ritter/ipo-data/). }\end{array}$ \\
\hline$\# R U N$ & $=$ The number of book runners for the IPO. \\
\hline$S A L E S_{P O S T}$ & $\begin{array}{l}=\text { Total Sales (SALE) for the fiscal year ending immediately following the } \\
\text { IPO, scaled by total assets. }\end{array}$ \\
\hline$S A L E S P S_{P R E}$ & $\begin{array}{l}=\text { Total sales (SALE) for the fiscal year ending immediately prior to the IPO, } \\
\text { scaled by shares outstanding immediately following the IPO. }\end{array}$ \\
\hline SCIPO & $\begin{array}{l}=\text { An indicator variable set to } 1 \text { if the IPO included a tax receivable agreement. } \\
\text { The tax receivable agreement requires that the firm provide between } 85- \\
90 \% \text { of the tax benefits associated with the deferred tax assets (existing } \\
\text { and/or newly created in conjunction with the IPO) to the pre-IPO owners } \\
\text { when the benefits are recognized. }\end{array}$ \\
\hline$\% S H A R E S$ & $=$ The percentage of total shares that are included in the initial public offering. \\
\hline$S I Z E_{P R E}$ & $=$ Logged value of total assets (AT) as of the fiscal year end prior to the IPO. \\
\hline SPREAD & $\begin{array}{l}=\text { The gross spread on the IPO, total fees (underwriting fee, management fee, } \\
\text { and selling concession) divided by total shares offered. }\end{array}$ \\
\hline UNDERPRICING & $\begin{array}{l}=\text { The percentage change in the share price during the first trading day of the } \\
\text { IPO. }\end{array}$ \\
\hline$V C \_B A C K E D$ & $=$ Indicator variable set to 1 if the IPO was backed by venture capital. \\
\hline$V W \_R E T U R N$ & $\begin{array}{l}=\text { Value weighted market return for the two calendar months prior to the firm's } \\
\text { IPO month. }\end{array}$ \\
\hline
\end{tabular}




\section{APPENDIX B \\ Excerpts from Form S-1 Disclosures by Supercharged IPO Sample Firms}

\section{Excerpts from the Form S-1/A for The Blackstone Group, L.P.:}

Below are excerpts from the Form S-1/A filed (on 6/21/2007) by The Blackstone Group, L.P. immediately before its IPO (where italic text indicates emphasis added by the authors). The excerpts describe the offering structure, the tax receivable agreement between the pre-IPO owners and the IPO firm, the magnitude of expected tax benefits, and various risk factors. Note that The Blackstone Group was organized as a flow-through entity both before and after IPO; that is, The Blackstone Group post-IPO is a publicly-traded partnership.

Exchange rights of holders of Blackstone Holdings partnership units. Prior to this offering we will enter into an exchange agreement with the holders of partnership units in Blackstone Holdings (other than The Blackstone Group L.P.'s wholly-owned subsidiaries) so that these holders, subject to the vesting and minimum retained ownership requirements and transfer restrictions set forth in the partnership agreements of the Blackstone Holdings partnerships, may up to four times each year (subject to the terms of the exchange agreement) exchange their Blackstone Holdings partnership units for The Blackstone Group L.P. common units on a one-for-one basis, subject to customary conversion rate adjustments for splits, unit distributions and reclassifications. A Blackstone Holdings limited partner must exchange one partnership unit in each of the five Blackstone Holdings partnerships to effect an exchange for a common unit. If and when an existing owner exchanges a Blackstone Holdings partnership unit for a common unit of The Blackstone Group L.P., the relative equity ownership positions of the exchanging existing owner and of the other equity owners of Blackstone (whether held at The Blackstone Group L.P. or at Blackstone Holdings) will not be altered. We have not yet determined how any such future exchanges will be accounted for in our consolidated financial statements.

Tax Receivable Agreement. The purchase of interests in our business from our existing owners with a portion of the proceeds from this offering as described in "Organizational Structure-Sale and Offering Transactions" and future exchanges of Blackstone Holdings partnership units are expected to result in increases in the tax basis of the tangible and intangible assets of Blackstone Holdings that would not otherwise have been available. These increases in tax basis will increase (for tax purposes) depreciation and amortization and therefore reduce the amount of tax that the wholly-owned subsidiaries of The Blackstone Group L.P. that are taxable as corporations for U.S. federal income tax purposes would otherwise be required to pay in the future. These wholly-owned subsidiaries will enter into a tax receivable agreement with our existing owners whereby they will agree to pay to our existing owners $85 \%$ of the amount of cash savings, if any, in U.S. federal, state and local income tax that these entities actually realize as a result of these increases in tax basis. Assuming no material changes in the relevant tax law and that we earn sufficient taxable income to realize the full tax benefit of the increased amortization of our assets, we expect that future payments to our existing owners in respect of the initial purchase will aggregate $\$ 863.7$ million and range from approximately $\$ 35.5$ million to $\$ 77.3$ million per year over the next 15 years (or $\$ 993.2$ million and range from approximately $\$ 40.8$ million to $\$ 88.9$ million per year 
over the next 15 years if the underwriters exercise in full their option to purchase additional common units).

Future payments to our existing owners in respect of subsequent exchanges would be in addition to these amounts and are expected to be substantial. The payments under the tax receivable agreement are not conditioned upon our existing owners' continued ownership of us. We may need to incur debt to finance payments under the tax receivable agreement to the extent our cash resources are insufficient to meet our obligations under the tax receivable agreement as a result of timing discrepancies or otherwise.

Risk Factors. Although we are not aware of any issue that would cause the IRS to challenge a tax basis increase, our existing owners will not reimburse us for any payments previously made under the tax receivable agreement. As a result, in certain circumstances payments to our existing owners under the tax receivable agreement could be in excess of the corporate taxpayers' cash tax savings. The corporate taxpayers' ability to achieve benefits from any tax basis increase, and the payments to be made under this agreement, will depend upon a number of factors, as discussed above, including the timing and amount of our future income.

\section{Excerpts from the Form S-1/A for GoDaddy, Inc.:}

Below are excerpts from the Form S-1/A filed (on 3/19/2015) by GoDaddy, Inc. immediately before its IPO (where italic text indicates emphasis added by the authors). The excerpts describe the offering structure, the tax receivable agreement between the pre-IPO owners and the IPO firm, the magnitude of expected tax benefits, and various risk factors. Note that GoDaddy, Inc. was organized as a flow-through entity before IPO, but as a $\mathrm{C}$ corporation after IPO.

Summary of Offering Structure. As used in this prospectus, "existing owners" refers to the owners of Desert Newco, collectively, prior to the Reorganization Transactions, and "Continuing LLC Owners" refers to those existing owners who will retain their equity ownership in Desert Newco in the form of LLC Units after the Reorganization Transactions.

- This offering is being conducted through what is commonly referred to as an "Up-C" structure, which is often used by partnerships and limited liability companies when they decide to undertake an initial public offering.

- The Up-C structure allows existing owners of a partnership or limited liability company to continue to realize the tax benefits associated with their ownership in an entity that is treated as a partnership for income tax purposes following an initial public offering, and provides tax benefits and associated cash flow to both the issuer corporation in the initial public offering and the existing owners of the partnership or limited liability company.

- Investors in this offering will purchase shares of our Class A common stock.

- Continuing LLC Owners will have the right to exchange their LLC Units, together with the corresponding shares of Class B common stock (which will be cancelled in connection with the exchange) for shares of our Class A common stock pursuant to the terms of an exchange agreement to be entered into in connection with this offering, or the Exchange Agreement. 
- Under various tax receivables agreements, or TRAs, to be entered into in connection with this offering, GoDaddy Inc. generally will retain approximately 15\% of certain tax savings that are available to it under the tax rules applicable to the Up-C structure, and generally will be required to pay approximately $85 \%$ of such tax savings to the existing owners.

Tax receivable agreements. Future exchanges of LLC Units, together with the corresponding shares of Class B common stock, for shares of our Class A common stock are expected to produce favorable tax attributes for us, as are the Investor Corp Mergers described under "Organizational Structure." These tax attributes would not be available to us in the absence of those transactions. Upon the closing of this offering, we will be a party to five TRAs. Under these agreements, we generally expect to retain the benefit of approximately $15 \%$ of the applicable tax savings after our payment obligations below are taken into account.

Under the first of those agreements, we generally will be required to pay to Continuing LLC Owners approximately $85 \%$ of the applicable savings, if any, in income tax that we are deemed to realize ... as a result of

- certain tax attributes that are created as a result of the exchanges of their LLC Units, together with the corresponding shares of Class B common stock, for shares of our Class A common stock;

- any existing tax attributes associated with their LLC Units the benefit of which is allocable to us as a result of the exchanges of their LLC Units, together with the corresponding shares of Class B common stock, for shares of our Class A common stock;

Risk Factors. The payment obligations under the TRAs are obligations of GoDaddy Inc., and we expect that the payments we will be required to make under the TRAs will be substantial. Assuming no material changes in the relevant tax law and that we earn sufficient taxable income to realize all tax benefits that are subject to the TRAs, we expect that the tax savings associated with (1) the Investor Corp Mergers and (2) future exchanges of LLC Units and shares of Class B common stock as described above would aggregate to approximately $\$ 1.6$ billion over 15 years from the date of this offering based upon an assumed initial public offering price of $\$ 18.00$ per share of our Class A common stock.... Under such scenario we would be required to pay the other parties to the TRAs approximately $85 \%$ of such amount, or $\$ 1.4$ billion, over the 15 year period from the date of this offering.

The actual existing tax basis and increase in tax basis, as well as the amount and timing of any payments under these agreements, will vary depending upon a number of factors, including the timing of exchanges by the holders of LLC Units, the price of our Class A common stock at the time of the exchange, whether such exchanges are taxable, the amount and timing of the taxable income we generate in the future, the federal tax rate then applicable and the portion of our payments under the TRAs constituting imputed interest.

Payments under the TRAs will be based on the tax reporting positions that we determine. Although we are not aware of any issue that would cause the IRS to challenge existing tax basis, a tax basis increase or other tax attributes subject to the TRAs, if any subsequent 
disallowance of tax basis or other benefits were so determined by the IRS, we would not be reimbursed for any payments previously made under the applicable TRAs (although we would reduce future amounts otherwise payable under such TRAs).

In certain cases, payments under the TRAs to our existing owners may be accelerated or significantly exceed the actual benefits we realize in respect of the tax attributes subject to the TRAs. The TRAs provide that (1) in the event that we materially breach any of our material obligations under the agreements, ... or (2) if, at any time, we elect an early termination of the agreements, our (or our successor's) obligations under the applicable agreements ... would accelerate and become payable in a lump sum amount equal to the present value of the anticipated future tax benefits calculated based on certain assumptions, ...

As a result of the foregoing, (1) we could be required to make payments under the TRAs that are greater than or less than the specified percentage of the actual tax savings we realize in respect of the tax attributes subject to the agreements and (2) if we materially breach a material obligation under the agreements or if we elect to terminate the agreements early, we would be required to make an immediate lump sum payment equal to the present value of the anticipated future tax savings, which payment may be made significantly in advance of the actual realization of such future tax savings. 


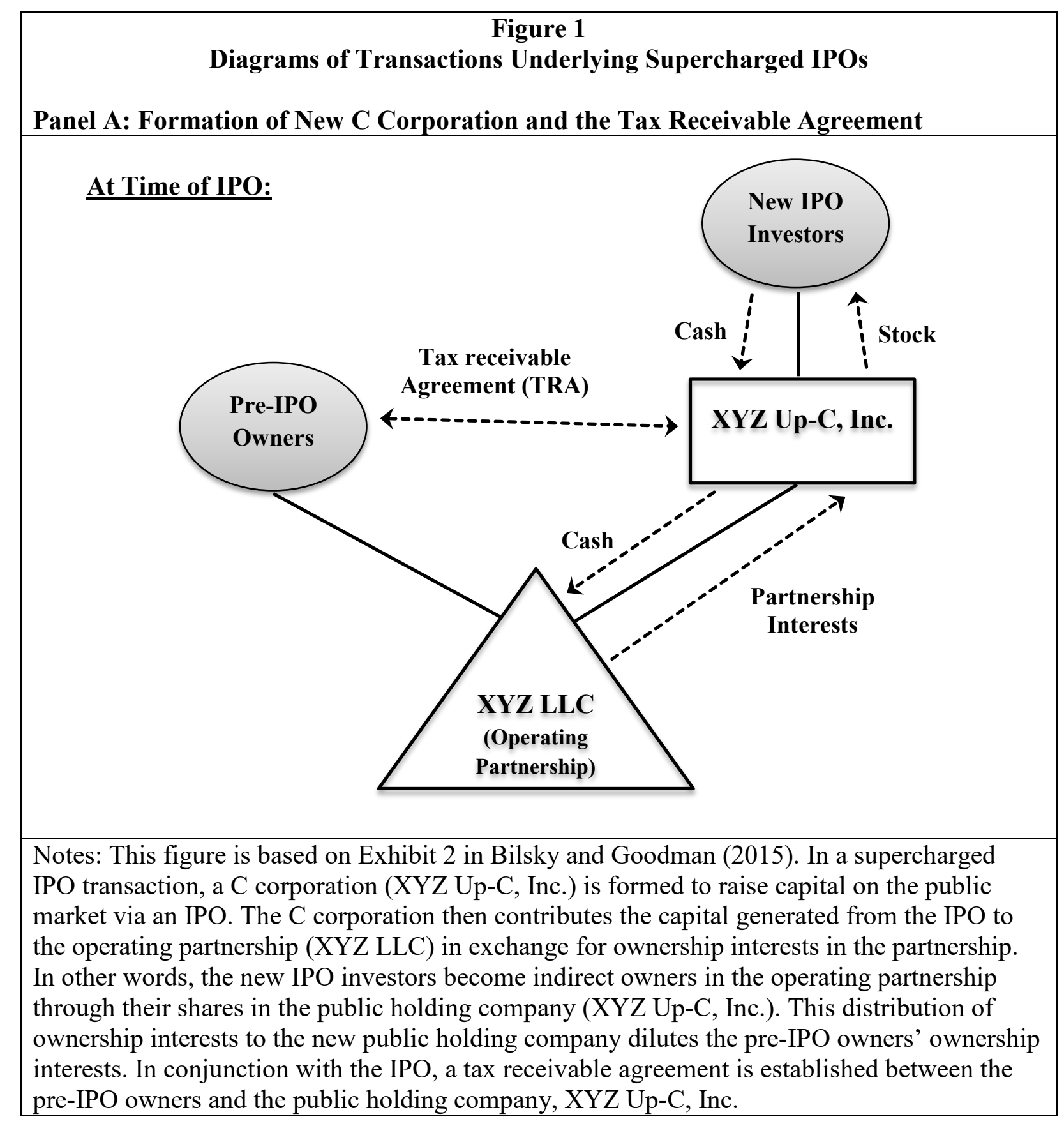




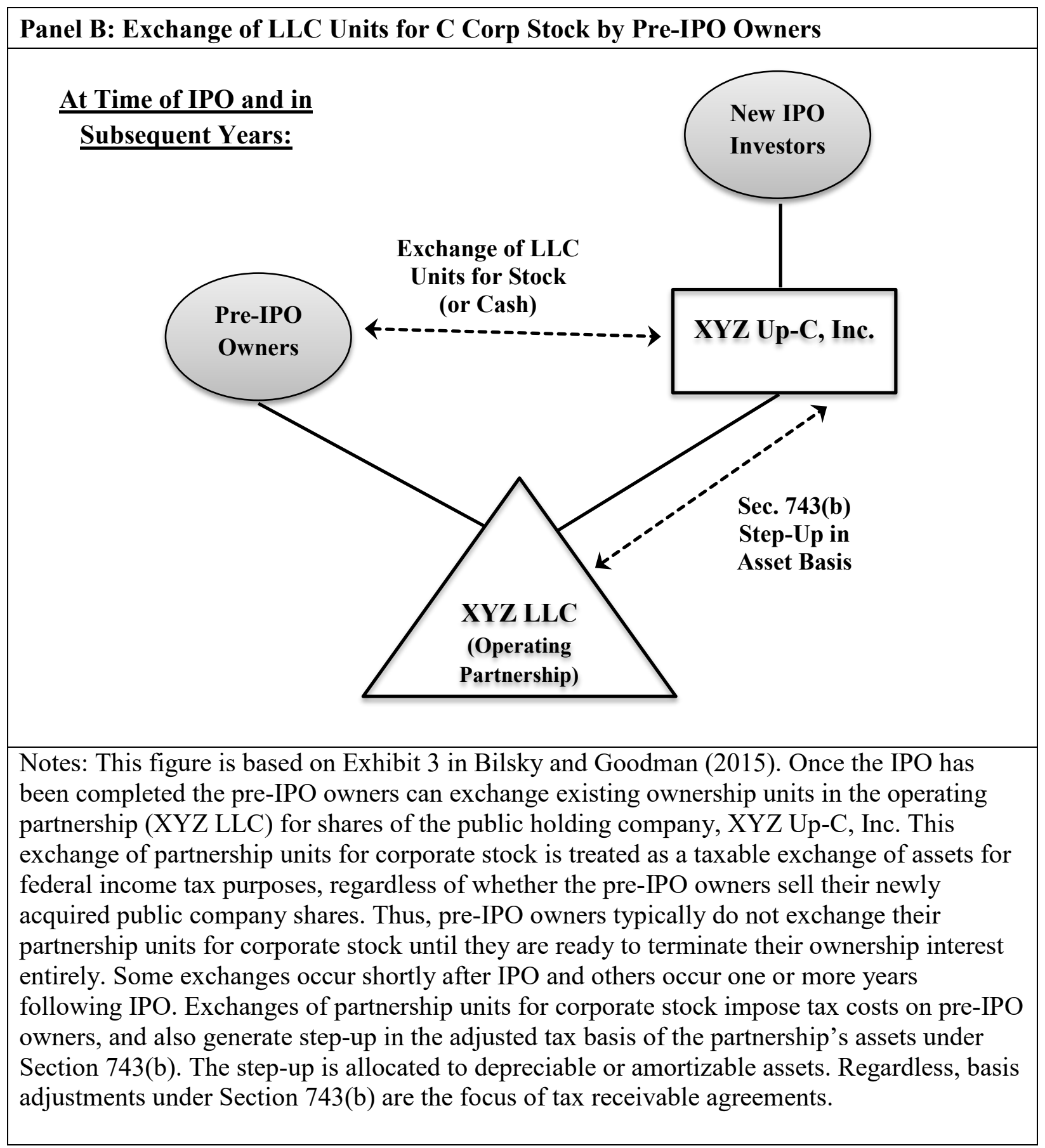




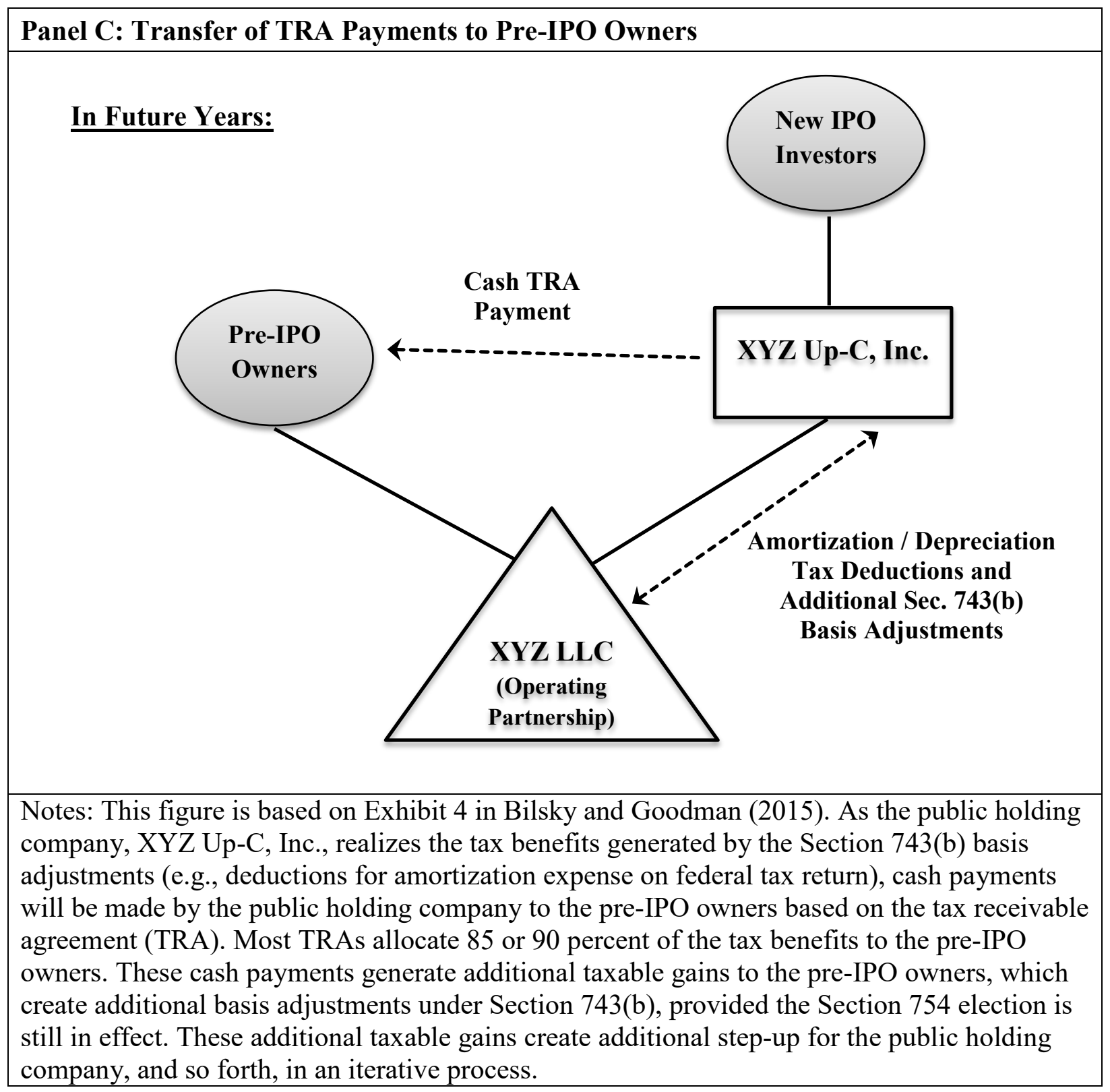


Figure 2

Comparisons of Financial Outcomes for Traditional and Supercharged IPOs under Different Assumptions

\begin{tabular}{|c|c|c|c|c|c|}
\hline & \multirow{2}{*}{$\begin{array}{c}\text { (1) } \\
\text { No IPO: } \\
\text { Pre-IPO Owner } \\
\text { Holds onto } \\
\text { Original Shares } \\
\end{array}$} & \multirow{2}{*}{$\begin{array}{c}\text { (2) } \\
\text { Traditional IPO: } \\
\text { Pre-IPO Owner } \\
\text { Sells all Shares } \\
\text { at IPO and Pays } \\
\text { Capital Gains Tax } \\
\end{array}$} & \multirow{2}{*}{$\begin{array}{c}\text { (3) } \\
\text { Supercharged IPO } \\
\text { Tax Benefits Split } \\
\text { b/t Pre-IPO Owner } \\
\text { and New Investors }\end{array}$} & \multicolumn{2}{|c|}{$\begin{array}{c}\text { (4) } \\
\text { IPO Owner Sells All Shares at IPO }\end{array}$} \\
\hline & & & & $\begin{array}{c}\text { New Investors } \\
\text { Indifferent } \mathrm{b} / \mathrm{t} \\
\text { Supercharged and } \\
\text { Traditional IPO } \\
\end{array}$ & $\begin{array}{l}\text { Pre-IPO Owner } \\
\text { Indifferent } \mathrm{b} / \mathrm{t} \\
\text { Supercharging and } \\
\text { Holding all Shares } \\
\end{array}$ \\
\hline (1) Unrecorded Intangible Pre-IPO & $\$ 100$ & $\$ 100$ & $\$ 100$ & $\$ 100$ & $\$ 100$ \\
\hline (2) Total IPO Proceeds & $\$ 0$ & $\$ 100$ & $\$ 100$ & $\$ 103.77$ & $\$ 97.56$ \\
\hline (3) Step-Up in Tax Basis at IPO & $\$ 0$ & $\$ 0$ & $\$ 100$ & $\$ 103.77$ & $\$ 97.56$ \\
\hline $\begin{array}{l}\text { (4) Future Tax Benefits of Step-Up } \\
=(3) \times 35 \%\end{array}$ & $\$ 0$ & $\$ 0$ & $\$ 35.00$ & $\$ 36.32$ & $\$ 34.15$ \\
\hline $\begin{array}{l}\text { (5) Present Value (PV) of Future Tax } \\
\text { Benefits in (4), where } r=5 \% ; n=15\end{array}$ & $\$ 0$ & $\$ 0$ & $\$ 24.22$ & $\$ 25.13$ & $\$ 23.63$ \\
\hline $\begin{array}{l}\text { (6) PV of Future Tax Benefits to } \\
\text { New Investor }=(5) \times 15 \%\end{array}$ & $\$ 0$ & $\$ 0$ & $\$ 3.63$ & $\$ 3.77$ & $\$ 3.54$ \\
\hline $\begin{array}{l}\text { (7) PV of Future Tax Benefits to } \\
\text { Pre-IPO Owner }=(5) \times 85 \% \\
\text { (8) Pre-IPO Owner's Tax Costs related } \\
\text { to }\end{array}$ & $\$ 0$ & $\$ 0$ & $\$ 20.59$ & $\$ 21.36$ & $\$ 20.08$ \\
\hline - Traditional IPO $=15 \% \times[(2)+(7)]$ & N/A & $\$ 15.00$ & N/A & N/A & N/A \\
\hline - Supercharged IPO $=15 \% \times[(3)+(7)]$ & $\mathrm{N} / \mathrm{A}$ & $\mathrm{N} / \mathrm{A}$ & $\$ 18.09$ & $\$ 18.77$ & $\$ 17.65$ \\
\hline $\begin{array}{l}\text { (9) Net Value to Pre-IPO Owners } \\
=(2)+(7)-(8) \\
\text { (10) Net Value to New Investors } \\
=(1)-(2)+(6)\end{array}$ & $\begin{array}{l}\$ 100^{21} \\
\$ 0\end{array}$ & $\begin{array}{l}\$ 85 \\
\$ 0\end{array}$ & $\begin{array}{l}\$ 102.50 \\
\$ 3.63\end{array}$ & $\begin{array}{l}\$ 106.36 \\
\$ 0\end{array}$ & $\begin{array}{l}\$ 100.00 \\
\$ 5.98\end{array}$ \\
\hline
\end{tabular}

${ }^{21}$ In column (1), the net value to pre-IPO owners is simply the unrecorded intangible asset [row (1)], and not the formula shown in row (9). 


\begin{abstract}
Notes: This figure illustrates different outcomes for traditional and supercharged-IPOs, where the IPO firm has $\$ 100$ of unrecorded intangible assets prior to IPO. Column (1) provides the benchmark "No IPO" scenario, where the pre-IPO owner holds onto their original ownership interest. Columns (2) and (3) both provide results for IPO transactions, where the new investors are willing to pay $\$ 100$ for the unrecorded intangible and the pre-IPO owner sells all of their original ownership interests ("shares") upon IPO. Column (2) presents results for a traditional IPO, where the sale of shares generates a capital gains tax liability for the pre-IPO owner (where the gain equals the amount of total IPO proceeds). Column (3) presents results for a supercharged IPO, where the sale / exchange of shares triggers step-up in asset basis for the IPO firm and a capital gains tax liability for the pre-IPO owner (where the tax liability is generated by the stepup in basis). In addition, the pre-IPO owner will pay capital gains tax in the future when s/he receives payments under the tax receivable agreement. Row (8) calculates the present value of all tax costs for the pre-IPO owner. Columns (4) and (5) present scenarios for two indifference points, where the total IPO proceeds no longer equal \$100. Column (4) assumes the new investors are willing to pay more than $\$ 100$ for the IPO because not only is there $\$ 100$ of unrecorded intangibles, but the firm also has future tax benefits related to the step-up in basis. An IPO price (total proceeds) of $\$ 103.77$ will keep the new investors indifferent between the supercharged and traditional IPO structures [net value to new investors $=\$ 0$ in row (10)]. The IPO price of $\$ 103.77$ generates $\$ 103.77$ of step-up, recorded as tax deductible goodwill. Column (5) instead assumes the new investors are not willing to pay $\$ 100$ for IPO shares, perhaps because they perceive the supercharging process as allowing pre-IPO owners to extract value from the firm. In this case, the new investors are only willing to pay $\$ 97.56$ (total proceeds) for the IPO shares, which will keep the pre-IPO owners indifferent between engaging in a supercharged IPO and the "no IPO" scenario in Column (1) [net value to pre-IPO owners $=\$ 100$ in row (9)]. The IPO price of $\$ 97.56$ generates $\$ 97.56$ of step-up, recorded as tax deductible goodwill. We note that for the sake of parsimony, Columns (3) - (5) ignore the additional step-up in asset basis that is generated in the future as payments are made to pre-IPO owners under the tax receivable agreement. These future payments generate additional taxable gain (for the pre-IPO owner) and additional step-up in basis (for the IPO firm), and so forth, in an iterative process in perpetuity. Calculations incorporating this iterative process are available from the authors upon request.
\end{abstract}


Figure 3

Numbers of Traditional and Supercharged IPOs by Year

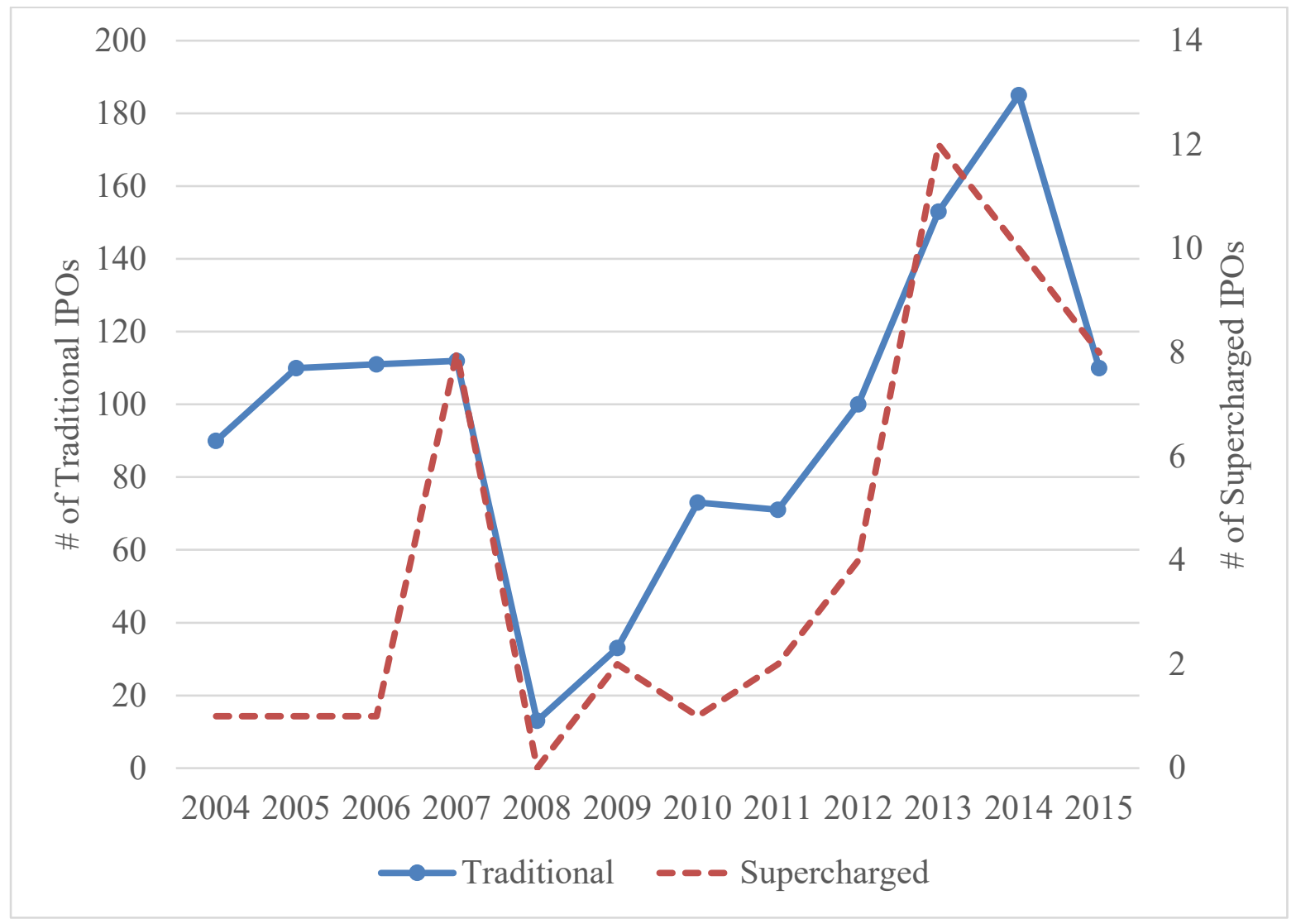


TABLE 1

Descriptive Statistics for Traditional and Supercharged IPO Firms

\begin{tabular}{|c|c|c|c|c|c|c|c|c|c|}
\hline \multirow[b]{2}{*}{ Variable } & \multicolumn{3}{|c|}{ Traditional IPO Firms $(\mathrm{N}=1,161)$} & \multicolumn{3}{|c|}{ Supercharged IPO Firms $(\mathrm{N}=50)$} & \multicolumn{3}{|c|}{ Test for Differences in } \\
\hline & Mean & Median & St Dev. & Mean & Median & St Dev. & Mean & t-value & \\
\hline \multicolumn{10}{|c|}{ Variables of Interest: } \\
\hline OFFER_PRICE & 2.587 & 2.639 & 0.442 & 2.915 & 2.890 & 0.316 & -0.328 & -5.198 & $* * *$ \\
\hline UNDERPRICING & 0.142 & 0.072 & 0.243 & 0.094 & 0.028 & 0.218 & 0.048 & 1.389 & \\
\hline$E B I T_{P O S T}$ & -0.076 & 0.034 & 0.342 & 0.139 & 0.103 & 0.191 & -0.215 & -3.953 & $* * *$ \\
\hline$S A L E S_{P O S T}$ & 0.825 & 0.610 & 0.880 & 0.982 & 0.702 & 1.048 & -0.157 & -1.099 & \\
\hline$C F O_{P O S T}$ & -0.093 & 0.013 & 0.354 & 0.106 & 0.088 & 0.248 & -0.199 & -3.513 & $* * *$ \\
\hline $2 M O R E T U R N S$ & 0.033 & 0.011 & 0.234 & -0.009 & 0.015 & 0.186 & 0.042 & 1.242 & \\
\hline $1 Y R$ RETURNS & 0.106 & 0.009 & 0.635 & -0.041 & -0.137 & 0.589 & 0.148 & 1.480 & \\
\hline \multicolumn{10}{|c|}{ Firm Characteristics: } \\
\hline$S I Z E_{P R E}$ & 4.846 & 4.616 & 1.988 & 6.347 & 6.258 & 2.042 & -1.502 & -5.223 & $* * *$ \\
\hline$P T I_{P R E}$ & -0.322 & -0.005 & 0.975 & -0.073 & 0.066 & 1.072 & -0.250 & -1.767 & $*$ \\
\hline$L E V_{P R E}$ & 0.865 & 0.718 & 0.945 & 1.023 & 0.673 & 1.313 & -0.158 & -1.140 & \\
\hline NetDTAPRE & -0.002 & 0.000 & 0.046 & 0.005 & 0.000 & 0.033 & -0.007 & -1.016 & \\
\hline$I_{N T A N G I B L E S_{P R E}}$ & 0.134 & 0.012 & 0.219 & 0.164 & 0.017 & 0.258 & -0.031 & -0.960 & \\
\hline$B V P S_{P R E}$ & 0.294 & 0.116 & 0.614 & 1.052 & 0.265 & 1.678 & -0.758 & -7.605 & $* * *$ \\
\hline$E P S_{P R E}$ & -0.002 & 0.000 & 0.008 & -0.001 & 0.000 & 0.009 & -0.001 & -1.240 & \\
\hline$S A L E S P S_{P R E}$ & 0.737 & 0.251 & 1.372 & 1.715 & 1.262 & 1.889 & -0.978 & -4.846 & $* * *$ \\
\hline$D T A P S_{P R E}$ & -0.012 & 0.000 & 0.076 & -0.007 & 0.000 & 0.085 & -0.005 & -0.447 & \\
\hline
\end{tabular}




\begin{tabular}{|c|c|c|c|c|c|c|c|c|c|}
\hline \multirow[b]{2}{*}{ Variable } & \multicolumn{3}{|c|}{ Traditional IPO Firms $(\mathrm{N}=1,161)$} & \multicolumn{3}{|c|}{ Supercharged IPO Firms $(\mathrm{N}=50)$} & \multicolumn{3}{|c|}{ Test for Differences in } \\
\hline & Mean & Median & St Dev. & Mean & Median & St Dev. & Mean & t-value & \\
\hline \multicolumn{10}{|c|}{ IPO Characteristics: } \\
\hline$\# L E A D$ & 5.722 & 5 & 3.762 & 9.220 & 7.5 & 4.568 & -3.498 & -6.38 & $* * *$ \\
\hline$\# R U N$ & 2.509 & 2 & 1.762 & 3.920 & 3 & 2.257 & -1.411 & -5.47 & $* * *$ \\
\hline$S P R E A D$ & 6.676 & 7.000 & 0.711 & 6.240 & 6.262 & 0.805 & 0.437 & 4.23 & $* * *$ \\
\hline$V C \_B A C K E D$ & 0.438 & 0 & 0.496 & 0.080 & 0 & 0.274 & 0.358 & 5.02 & $* * *$ \\
\hline$P E \_B A C K E D$ & 0.281 & 0 & 0.450 & 0.460 & 0 & 0.503 & -0.179 & -2.74 & $* * *$ \\
\hline$B I G N$ & 0.779 & 1 & 0.415 & 0.860 & 1 & 0.351 & -0.081 & -1.36 & \\
\hline$B I G L A W$ & 0.284 & 0 & 0.451 & 0.360 & 0 & 0.485 & -0.076 & -1.16 & \\
\hline $\begin{array}{l}\text { RANK_} \\
\text { UNDERWRITER }\end{array}$ & 4.046 & 8.001 & 7.251 & 4.441 & 9.001 & 7.645 & -0.395 & -0.38 & \\
\hline$\% S H A R E S$ & 0.287 & 0.252 & 0.157 & 0.604 & 0.558 & 0.295 & -0.318 & -13.32 & $* * *$ \\
\hline PROCEEDS & 2.442 & 0.922 & 6.552 & 1.086 & 0.451 & 1.811 & 1.356 & 1.46 & \\
\hline IPOTOT & 38.792 & 38 & 13.112 & 40.260 & 42.5 & 12.289 & -1.468 & -0.78 & \\
\hline IPORET & 63.543 & 22.061 & 216.419 & 105.420 & 25.486 & 315.388 & -41.877 & -1.31 & \\
\hline$V W \_R E T U R N$ & 1.028 & 1.030 & 0.038 & 1.027 & 1.029 & 0.031 & 0.000 & 0.07 & \\
\hline$L O \bar{C} K U P$ & 0.643 & 1 & 0.479 & 0.480 & 0 & 0.505 & 0.163 & 2.35 & $* *$ \\
\hline
\end{tabular}

Notes: ${ }^{*},{ }^{* *},{ }^{* * *}$ indicate statistical significance at the 10,5, and 1 percent levels, respectively, based on two-sided tests. Variables are defined in Appendix A. 
TABLE 2

The Amount of Tax Benefits Generated by Step-Up in Asset Basis as Disclosed by Supercharged IPO Sample Firms in SEC Filings

\begin{tabular}{|c|c|c|c|c|c|c|c|c|c|c|c|c|}
\hline & Firm & $\begin{array}{l}\text { (1) } \\
\text { IPO } \\
\text { Year } \\
\end{array}$ & $\begin{array}{c}(2) \\
\text { Enterprise } \\
\text { Value at FYE } \\
\text { post-IPO } \\
\text { (millions) } \\
\end{array}$ & $\begin{array}{c}\text { (3) } \\
\text { IPO } \\
\text { Price } \\
\text { (Per } \\
\text { Share) } \\
\end{array}$ & \multicolumn{3}{|c|}{$\begin{array}{c}(4) \\
\text { Increase in the Deferred Tax } \\
\text { Assets at IPO, as Reported in Pro } \\
\text { Forma Financial Statements }\end{array}$} & \multicolumn{3}{|c|}{$\begin{array}{c}(6) \quad(7) \\
\text { Anticipated Increase in } \\
\text { Deferred Tax Assets, Assuming } \\
\text { Share Transfers Following IPO }\end{array}$} & \multicolumn{2}{|c|}{$\begin{array}{c}(8) \quad(9) \\
\text { Actual Post-IPO } \\
\text { Payments under the Tax } \\
\text { Receivable Agreement }\end{array}$} \\
\hline (1) & Adeptus Health Inc. & 2014 & 470.44 & 22 & 32.4 & & 3.21 & 131.57 & (d) & 13.01 & 0.00 & 0.00 \\
\hline (2) & Amplify Snack Brands, INC & 2015 & 974.26 & 18 & NR & & NR & 112.40 & & 1.50 & 13.71 & 0.18 \\
\hline (3) & Apollo Global Management LLC & 2011 & $4,538.98$ & 19 & NR & & NR & 578.12 & (d) & 4.78 & 84.80 & 0.70 \\
\hline (4) & Ares Management LP & 2014 & $13,337.11$ & 19 & NR & & NR & 896.00 & (e) & 11.11 & 0.00 & 0.00 \\
\hline (5) & Artio Global Investors Inc. & 2009 & $1,528.94$ & 26 & 39.32 & & 1.42 & 310.10 & & 11.21 & 5.10 & 0.18 \\
\hline (6) & Artisan Partners Asset Mgmt Inc. & 2013 & $1,259.04$ & 30 & 57.2 & & 0.81 & 855.60 & & 12.12 & 24.80 & 0.35 \\
\hline (7) & Athlon Energy Inc & 2013 & $2,871.38$ & 20 & NR & & NR & 6.24 & (e) & 0.04 & 0.00 & 0.00 \\
\hline (8) & Blackstone Group L.P. & 2007 & $4,806.49$ & 31 & 1061.1 & & 4.17 & ND & & ND & 72.60 & 0.29 \\
\hline (9) & Cloud Peak Energy Inc. & 2009 & 827.81 & 15 & 76.73 & & 2.44 & ND & & ND & 19.10 & 0.61 \\
\hline$(10)$ & Dreamworks Animation Inc & 2004 & $4,015.72$ & 28 & NR & & NR & ND & & ND & 65.61 & 0.62 \\
\hline (12) & Edgen Group Inc. & 2012 & 930.04 & 11 & NR & & NR & 52.30 & & 1.24 & 0.00 & 0.00 \\
\hline (13) & Evercore Partners Inc & 2006 & 84.93 & 21 & NR & & NR & NR & & NR & 1.81 & 0.39 \\
\hline (14) & Evolent Health, Inc. & 2015 & 554.81 & 17 & NR & & NR & 136.47 & (d) & 1.98 & 0.00 & 0.00 \\
\hline$(15)$ & Fifth Street Asset Mgmt Inc. & 2014 & 96.46 & 17 & 56.6 & & 1.16 & ND & & ND & 3.11 & 0.06 \\
\hline (16) & Foresight Energy LP & 2014 & $3,670.40$ & 20 & NR & & NR & ND & & ND & 0.00 & 0.00 \\
\hline (17) & Fortress Investment Group LLC & 2007 & $1,910.15$ & 18.5 & 511.79 & & 5.73 & 945.20 & & 10.58 & 33.00 & 0.37 \\
\hline (18) & Frank's International N.V. & 2013 & $3,740.20$ & 22 & 77.39 & & 0.5 & ND & & ND & 0.00 & 0.00 \\
\hline (19) & FXCM Inc. & 2010 & 36.15 & 14 & 73.88 & & 4.27 & ND & & ND & 4.98 & 0.29 \\
\hline$(20)$ & GoDaddy Inc. & 2015 & $2,862.58$ & 20 & 196.87 & (a) & 1.27 & 1600.00 & & 10.31 & 0.00 & 0.00 \\
\hline$(21)$ & Habit Restaurants, Inc. & 2014 & 243.35 & 18 & 12.36 & & 0.48 & ND & & ND & 4.03 & 0.15 \\
\hline$(22)$ & Health Insurance Innovations, Inc. & 2013 & 23.85 & 14 & NR & & NR & 67.21 & & 5.04 & 0.00 & 0.00 \\
\hline$(23)$ & HFF, Inc. & 2007 & 83.29 & 18 & 106.4 & & 6.47 & ND & & ND & 7.52 & 0.46 \\
\hline (24) & Jones Energy, Inc. & 2013 & 815.53 & 15 & 6.74 & & 0.13 & 368.50 & & 7.25 & 0.00 & 0.00 \\
\hline$(25)$ & Ladder Capital Corp & 2014 & $2,927.14$ & 17 & NR & & NR & ND & & ND & 0.00 & 0.00 \\
\hline$(26)$ & Lazard Ltd & 2005 & $1,905.91$ & 25 & 0 & (b) & 0 & 1700.00 & & 45.33 & 8.65 & 0.23 \\
\hline (29) & Medley Management Inc. & 2014 & 202.83 & 18 & NR & & NR & 290.71 & (e) & 48.45 & 0.00 & 0.00 \\
\hline$(30)$ & National CineMedia, Inc. \# & 2007 & $1,812.92$ & 21 & 223.7 & & 5.33 & ND & & ND & 27.80 & 0.66 \\
\hline
\end{tabular}




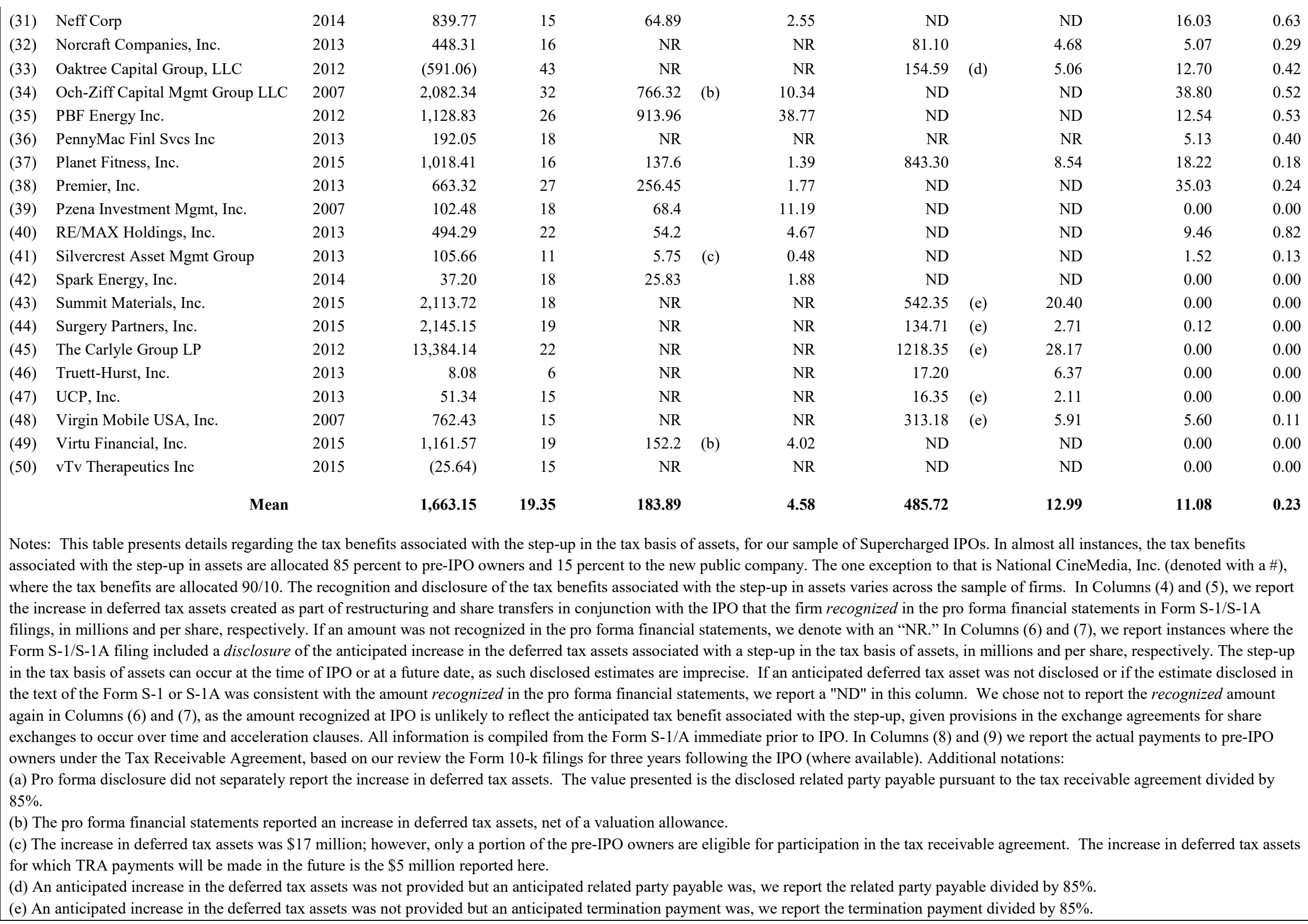


TABLE 3

Industry Composition of Traditional and Supercharged IPOs

Panel A: Fama-French 48 Industries

\begin{tabular}{|c|c|c|c|c|}
\hline & \multicolumn{2}{|c|}{ Traditional IPOs } & \multicolumn{2}{|c|}{ Supercharged IPOs } \\
\hline Food Products & 7 & $0.60 \%$ & 0 & $0.00 \%$ \\
\hline Candy \& Soda & 1 & $0.09 \%$ & 1 & $2.00 \%$ \\
\hline Beer \& Liquor & 1 & $0.09 \%$ & 1 & $2.00 \%$ \\
\hline Recreation & 2 & $0.17 \%$ & 1 & $2.00 \%$ \\
\hline Entertainment & 6 & $0.52 \%$ & 2 & $4.00 \%$ \\
\hline Printing \& Publishing & 1 & $0.09 \%$ & 0 & $0.00 \%$ \\
\hline Consumer Goods & 9 & $0.78 \%$ & 0 & $0.00 \%$ \\
\hline Apparel & 7 & $0.60 \%$ & 0 & $0.00 \%$ \\
\hline Healthcare & 28 & $2.41 \%$ & 2 & $4.00 \%$ \\
\hline Medical Equipment & 75 & $6.46 \%$ & 0 & $0.00 \%$ \\
\hline Pharmaceutical Products & 213 & $18.35 \%$ & 1 & $2.00 \%$ \\
\hline Chemicals & 23 & $1.98 \%$ & 0 & $0.00 \%$ \\
\hline Rubber \& Plastic Products & 5 & $0.43 \%$ & 0 & $0.00 \%$ \\
\hline Textiles & 1 & $0.09 \%$ & 0 & $0.00 \%$ \\
\hline Construction Materials & 6 & $0.52 \%$ & 1 & $2.00 \%$ \\
\hline Construction & 12 & $1.03 \%$ & 1 & $2.00 \%$ \\
\hline Steel Works & 5 & $0.43 \%$ & 0 & $0.00 \%$ \\
\hline Fabricated Products & 1 & $0.09 \%$ & 0 & $0.00 \%$ \\
\hline Machinery & 14 & $1.21 \%$ & 0 & $0.00 \%$ \\
\hline Electronic Equipment & 8 & $0.69 \%$ & 0 & $0.00 \%$ \\
\hline Automobiles \& Trucks & 9 & $0.78 \%$ & 0 & $0.00 \%$ \\
\hline Aircraft & 3 & $0.26 \%$ & 0 & $0.00 \%$ \\
\hline Shipbuilding \& Railroad Equipment & 2 & $0.17 \%$ & 0 & $0.00 \%$ \\
\hline Non-Metallic \& Industrial Metal Mining & 4 & $0.34 \%$ & 1 & $2.00 \%$ \\
\hline Coal & 2 & $0.17 \%$ & 2 & $4.00 \%$ \\
\hline Petroleum \& Natural Gas & 56 & $4.82 \%$ & 4 & $8.00 \%$ \\
\hline
\end{tabular}




\begin{tabular}{|c|c|c|c|c|}
\hline Utilities & 25 & $2.15 \%$ & 1 & $2.00 \%$ \\
\hline Communication & 25 & $2.15 \%$ & 1 & $2.00 \%$ \\
\hline Personal Services & 9 & $0.78 \%$ & 0 & $0.00 \%$ \\
\hline Business Services & 220 & $18.95 \%$ & 5 & $10.00 \%$ \\
\hline Computers & 22 & $1.89 \%$ & 0 & $0.00 \%$ \\
\hline Electrical Equipment & 47 & $4.05 \%$ & 0 & $0.00 \%$ \\
\hline Measuring \& Control Equipment & 9 & $0.78 \%$ & 0 & $0.00 \%$ \\
\hline Business Supplies & 3 & $0.26 \%$ & 0 & $0.00 \%$ \\
\hline Shipping Containers & 1 & $0.09 \%$ & 0 & $0.00 \%$ \\
\hline Transportation & 18 & $1.55 \%$ & 0 & $0.00 \%$ \\
\hline Wholesale & 17 & $1.46 \%$ & 1 & $2.00 \%$ \\
\hline Retail & 49 & $4.22 \%$ & 0 & $0.00 \%$ \\
\hline Restaurants, Hotels \& Motels & 31 & $2.67 \%$ & 1 & $2.00 \%$ \\
\hline Banks & 54 & $4.65 \%$ & 1 & $2.00 \%$ \\
\hline Insurance & 22 & $1.89 \%$ & 1 & $2.00 \%$ \\
\hline Real Estate & 10 & $0.86 \%$ & 3 & $6.00 \%$ \\
\hline Trading & 94 & $8.10 \%$ & 19 & $38.00 \%$ \\
\hline Other & 4 & $0.34 \%$ & 0 & $0.00 \%$ \\
\hline \multicolumn{5}{|l|}{ Panel B: Fama-French 5 Industries } \\
\hline & \multicolumn{2}{|c|}{ Traditional IPOs } & \multicolumn{2}{|c|}{ Supercharged IPOs } \\
\hline $\begin{array}{l}\text { Consumer Durables, NonDurables, Wholesale, } \\
\text { Retail, and some Services }\end{array}$ & 123 & $10.59 \%$ & 4 & $8.00 \%$ \\
\hline Manufacturing, Energy, and Utilities & 157 & $13.52 \%$ & 8 & $16.00 \%$ \\
\hline $\begin{array}{l}\text { Business Equipment, Telephone, and Television } \\
\text { Transmission }\end{array}$ & 272 & $23.43 \%$ & 2 & $4.00 \%$ \\
\hline Healthcare, Medical Equipment, and Drugs & 316 & $27.22 \%$ & 3 & $6.00 \%$ \\
\hline Other & 293 & $25.24 \%$ & 33 & $66.00 \%$ \\
\hline
\end{tabular}


TABLE 4

Pearson Correlations between Supercharged IPO Indicator Variable (SCIPO) and IPO Pricing and Future Performance Measures

\begin{tabular}{|c|c|c|c|c|c|c|c|c|}
\hline & SCIPO & $\begin{array}{l}\text { OFFER_- } \\
\text { PRICE }\end{array}$ & $\begin{array}{l}\text { UNDER } \\
\text { PRICING }\end{array}$ & $E B I T_{P O S T}$ & $S A L E S_{P O S T}$ & $C F O_{P O S T}$ & $\begin{array}{c}2 M O \\
\text { RETURN }\end{array}$ & $\begin{array}{c}1 Y R \\
\text { RETURN }\end{array}$ \\
\hline SCIPO & 1 & & & & & & & \\
\hline OFFER_PRICE & $0.1478^{*}$ & 1 & & & & & & \\
\hline UNDERPRICING & -0.0399 & $0.2527^{*}$ & 1 & & & & & \\
\hline$E B I T_{P O S T}$ & $0.1211^{*}$ & $0.4619^{*}$ & $0.1352^{*}$ & 1 & & & & \\
\hline$S A L E S_{P O S T}$ & 0.0339 & $0.1327^{*}$ & $0.1259^{*}$ & $0.4581^{*}$ & 1 & & & \\
\hline$C F O_{P O S T}$ & $0.1078^{*}$ & $0.4545^{*}$ & $0.1470^{*}$ & $0.9764^{*}$ & $0.4421^{*}$ & 1 & & \\
\hline 2 MO RETURNS & -0.0358 & 0.0047 & -0.0148 & $0.0931^{*}$ & $0.0629^{*}$ & $0.1013^{*}$ & 1 & \\
\hline 1 YR RETURNS & -0.0449 & -0.0193 & $-0.0983^{*}$ & $0.0852^{*}$ & $0.0900^{*}$ & $0.1038^{*}$ & $0.3754^{*}$ & 1 \\
\hline
\end{tabular}

Notes: This table presents Pearson correlation coefficients in the lower diagonal. ${ }^{*}$ indicates the correlation coefficients are significant at the $5 \%$ level or better. All variables are as defined in Appendix A. 
TABLE 5

Results for OLS Regressions of IPO Offer Price (OFFER_PRICE) on the Indicator for Supercharged IPOs (SCIPO) and Control Variables

\begin{tabular}{|c|c|c|c|c|}
\hline & \multicolumn{2}{|c|}{ (1) } & \multicolumn{2}{|c|}{ (2) } \\
\hline & Coefficient & t-stat & Coefficient & t-stat \\
\hline SCIPO & 0.153 & $3.07^{* * *}$ & 0.151 & $3.04^{* * *}$ \\
\hline$D T A P S_{P R E}$ & & & 0.218 & 1.55 \\
\hline$B V P S_{P R E}$ & 0.087 & $4.87^{* * *}$ & 0.086 & $4.88^{* * *}$ \\
\hline$E P S_{P R E}$ & 10.563 & $4.20^{* * *}$ & 10.52 & $4.18^{* * *}$ \\
\hline$S A L E S P S_{P R E}$ & 0.020 & $2.54^{* *}$ & 0.021 & $2.76^{* * *}$ \\
\hline SPREAD & -0.131 & $-6.86^{* * *}$ & -0.133 & $-6.95^{* * *}$ \\
\hline PROCEEDS & 0.007 & $2.80^{* * *}$ & 0.007 & $2.8^{* * *}$ \\
\hline$\% S H A R E S$ & -0.268 & $-3.7^{* * *}$ & -0.274 & $-3.79^{* * *}$ \\
\hline IPOTOT & -0.001 & -1.41 & -0.001 & -1.36 \\
\hline IPORET & 0.000 & 0.47 & 0.000 & 0.48 \\
\hline$V W \_R E T U R N$ & 0.276 & 0.91 & 0.276 & 0.91 \\
\hline$V C_{-}{ }^{-} B A C K E D$ & 0.108 & $2.94^{* * *}$ & 0.107 & $2.93^{* * *}$ \\
\hline$P E \_B A C K E D$ & 0.080 & $2.78^{* * *}$ & 0.085 & $2.93^{* * *}$ \\
\hline$B I \overline{I G N}$ & 0.167 & $5.89^{* * *}$ & 0.168 & $5.89^{* * *}$ \\
\hline$B I G L A W$ & 0.064 & $2.81^{* * *}$ & 0.064 & $2.81^{* * *}$ \\
\hline RANK_UNDERWRITER & 0.002 & 1.39 & 0.002 & 1.37 \\
\hline Intercept & 3.141 & $9.69^{* * *}$ & 3.155 & $9.71^{* * *}$ \\
\hline Fixed Effects & \multicolumn{2}{|c|}{ Industry \& Year } & \multicolumn{2}{|c|}{ Industry \& Year } \\
\hline \# of Obs & \multicolumn{2}{|c|}{1,211} & \multicolumn{2}{|c|}{1,211} \\
\hline Adjusted $\mathrm{R}^{2}$ & \multicolumn{2}{|c|}{0.3544} & \multicolumn{2}{|c|}{0.3552} \\
\hline
\end{tabular}

Notes: All regressions include industry fixed effects, year fixed effects, and robust standard errors. ${ }^{* * *},{ }^{* * *}$ indicate statistical significance at the 10,5, and 1 percent levels, respectively, based on two-sided t-tests. Variables are defined in Appendix A. 
TABLE 6

Results for OLS Regressions of the Percentage Change in Stock Price on the First Day of Trading (UNDERPRICING) on the Indicator for Supercharged IPOs (SCIPO) and Control Variables

\begin{tabular}{|c|c|c|c|c|}
\hline & \multicolumn{2}{|c|}{ (1) } & \multicolumn{2}{|c|}{ (2) } \\
\hline & Coefficient & t-stat & Coefficient & t-stat \\
\hline SCIPO & -0.002 & -0.05 & -0.003 & -0.08 \\
\hline$D T A P S_{P R E}$ & & & 0.113 & 1.38 \\
\hline$B V P S_{P R E}$ & -0.021 & $-1.89^{*}$ & -0.021 & $-1.95^{*}$ \\
\hline$E P S_{P R E}$ & 2.567 & $2.26^{* *}$ & 2.555 & $2.25^{* *}$ \\
\hline SALESPS $P R E$ & -0.012 & $-2.81^{* * *}$ & -0.012 & $-2.68^{* * *}$ \\
\hline OFFER_PRICE & 0.165 & $8.17^{* * *}$ & 0.164 & $8.10^{* * *}$ \\
\hline SPREAD & 0.027 & $1.99^{* *}$ & 0.026 & $1.89^{*}$ \\
\hline PROCEEDS & 0.001 & 1.25 & 0.001 & 1.24 \\
\hline$\% S H A R E S$ & -0.134 & $-2.62^{* * *}$ & -0.138 & $-2.70^{* * *}$ \\
\hline IPOTOT & 0.000 & 0.82 & 0.001 & 0.85 \\
\hline IPORET & 0.000 & -0.50 & 0.000 & -0.50 \\
\hline$V W \_R E T U R N$ & 0.056 & 0.33 & 0.056 & 0.34 \\
\hline$V C \_B A C K E D$ & 0.096 & $4.99^{* * *}$ & 0.096 & $5.00^{* * *}$ \\
\hline$P E \_B A C K E D$ & -0.004 & -0.26 & -0.001 & -0.08 \\
\hline$B I G N$ & 0.014 & 0.85 & 0.015 & 0.89 \\
\hline$B I G L A W$ & -0.007 & -0.47 & -0.007 & -0.47 \\
\hline RANK_UNDERWRITER & -0.001 & -1.00 & -0.001 & -1.02 \\
\hline Intercept & -0.415 & $-1.85^{*}$ & -0.405 & $-1.79^{*}$ \\
\hline Fixed Effects & \multicolumn{2}{|c|}{ Industry \& Year } & \multicolumn{2}{|c|}{ Industry \& Year } \\
\hline$\#$ of Obs & \multicolumn{2}{|c|}{1,211} & \multicolumn{2}{|c|}{1,211} \\
\hline Adjusted $\mathrm{R}^{2}$ & \multicolumn{2}{|c|}{0.1829} & \multicolumn{2}{|c|}{0.1834} \\
\hline
\end{tabular}

Notes: All regressions include industry fixed effects, year fixed effects, and robust standard errors. ${ }^{*},{ }^{* *},{ }^{* *}$ indicate statistical significance at the 10,5, and 1 percent levels, respectively, based on two-sided t-tests. Variables are defined in Appendix A. 
TABLE 7

Results for OLS Regressions of Measures of Future Firm Accounting Performance on the Indicator for Supercharged IPOs (SCIPO) and Control Variables

\begin{tabular}{|c|c|c|c|c|c|c|}
\hline & \multicolumn{2}{|c|}{$\begin{array}{c}(1) \\
\text { Dependent } \mathrm{Var}= \\
E B I T_{P O S T}\end{array}$} & \multicolumn{2}{|c|}{$\begin{array}{c}(2) \\
\text { Dependent } \mathrm{Var}= \\
S A L E S_{P O S T}\end{array}$} & \multicolumn{2}{|c|}{$\begin{array}{c}(3) \\
\text { Dependent Var }= \\
C F O_{P O S T}\end{array}$} \\
\hline & Coeff & t-stat & Coeff & t-stat & Coeff & t-stat \\
\hline SCIPO & 0.066 & $1.69^{*}$ & 0.149 & 1.24 & 0.053 & 1.15 \\
\hline$L A G \_P E R F O R M$ & 0.040 & $6.01^{* * *}$ & 0.313 & $9.35^{* * *}$ & 0.024 & $5.35^{* * *}$ \\
\hline$S I Z E_{P R E}$ & 0.032 & $5.90^{* * *}$ & 0.032 & $2.53^{* *}$ & 0.031 & $5.14^{* * *}$ \\
\hline Intercept & -0.059 & $-1.66^{*}$ & 1.036 & $6.43^{* * *}$ & -0.070 & $-1.77^{*}$ \\
\hline Fixed Effects & \multirow{2}{*}{\multicolumn{2}{|c|}{$\begin{array}{c}\text { Industry \& Year } \\
9599\end{array}$}} & \multicolumn{2}{|c|}{ Industry \& Year } & \multicolumn{2}{|c|}{ Industry \& Year } \\
\hline \# of Obs & & & \multicolumn{2}{|c|}{959} & \multicolumn{2}{|c|}{959} \\
\hline Adjusted $\mathrm{R}^{2}$ & \multicolumn{2}{|c|}{0.5367} & \multicolumn{2}{|c|}{0.5724} & \multicolumn{2}{|c|}{0.4717} \\
\hline
\end{tabular}


TABLE 8

Results for OLS Regressions of Measures of Future Firm Stock Returns on the Indicator for Supercharged IPOs (SCIPO) and Control Variables

\begin{tabular}{|c|c|c|c|c|}
\hline & \multicolumn{2}{|c|}{$\begin{array}{c}(1) \\
\text { Dependent } \mathrm{Var}= \\
2 M O R E T U R N S\end{array}$} & \multicolumn{2}{|c|}{$\begin{array}{c}(2) \\
\text { Dependent } \mathrm{Var}= \\
1 Y R \text { RETURNS }\end{array}$} \\
\hline & Coeff & t-stat & Coeff & t-stat \\
\hline SCIPO & -0.038 & -1.52 & -0.058 & -0.69 \\
\hline$M K T$ & 1.510 & $8.38^{* * *}$ & 1.444 & $6.84^{* * *}$ \\
\hline$S M B$ & 0.831 & $2.86^{* * *}$ & 1.652 & $3.73^{* * *}$ \\
\hline$H M L$ & -0.671 & $-2.49^{* *}$ & -0.087 & -0.25 \\
\hline Intercept & 0.060 & $2.58^{* * *}$ & -0.025 & -0.35 \\
\hline Fixed Effects & \multirow{2}{*}{\multicolumn{2}{|c|}{$\begin{array}{c}\text { Industry \& Year } \\
1,077\end{array}$}} & \multirow{2}{*}{\multicolumn{2}{|c|}{$\begin{array}{c}\text { Industry \& Year } \\
1,077\end{array}$}} \\
\hline$\#$ of Obs & & & & \\
\hline Adjusted $\mathrm{R}^{2}$ & \multicolumn{2}{|c|}{0.1045} & \multicolumn{2}{|c|}{0.1113} \\
\hline
\end{tabular}

Notes: All regressions include industry (Fama French 5) fixed effects, year fixed effects, and robust standard errors. $*, * *, * * *$ indicate statistical significance at the 10,5 , and 1 percent levels, respectively, based on twosided t-tests. Variables are defined in Appendix A. 
TABLE 9

Results for OLS Regressions of IPO Offer Prices (OFFER_PRICE) on the Indicator for Supercharged IPOs (SCIPO), a Stock Lock-Up Indicator Variable (LOCKUP), $S C I P O \times L O C K U P$, and Control Variables

\begin{tabular}{|c|c|c|c|c|}
\hline & \multicolumn{2}{|c|}{ (1) } & \multicolumn{2}{|c|}{ (2) } \\
\hline & Coefficient & t-stat & Coefficient & t-stat \\
\hline SCIPO & 0.217 & $3.41^{* * *}$ & 0.216 & $3.42^{* * *}$ \\
\hline$S C I P O \times L O C K U P$ & -0.157 & $-1.76^{*}$ & -0.161 & $-1.82^{*}$ \\
\hline$L O C K U P$ & 0.038 & 1.32 & 0.038 & 1.34 \\
\hline$D T A P S_{P R E}$ & & & 0.224 & 1.59 \\
\hline$B V P S_{P R E}$ & 0.088 & $4.93^{* * *}$ & 0.087 & $4.94^{* * *}$ \\
\hline$E P S_{P R E}$ & 10.226 & $4.05^{* * *}$ & 10.174 & $4.02^{* * *}$ \\
\hline$S A L E S P S_{P R E}$ & 0.021 & $2.68^{* * *}$ & 0.022 & $2.91^{* * *}$ \\
\hline$S P R E A D$ & -0.129 & $-6.68^{* * *}$ & -0.131 & $-6.78^{* * *}$ \\
\hline PROCEEDS & 0.007 & $2.75^{* * *}$ & 0.007 & $2.74^{* * *}$ \\
\hline$\% S H A R E S$ & -0.216 & $-2.53^{* *}$ & -0.221 & $-2.60^{* * *}$ \\
\hline IPOTOT & -0.001 & -1.39 & -0.001 & -1.34 \\
\hline IPORET & 0.000 & 0.50 & 0.000 & 0.50 \\
\hline$V W \_R E T U R N$ & 0.309 & 1.01 & 0.310 & 1.02 \\
\hline$V C \_B A C K E D$ & 0.107 & $2.91^{* * *}$ & 0.106 & $2.90^{* * *}$ \\
\hline$P E \_B A C K E D$ & 0.082 & $2.85^{* * *}$ & 0.087 & $3.01^{* * *}$ \\
\hline$B I G N$ & 0.165 & $5.79^{* * *}$ & 0.166 & $5.79^{* * *}$ \\
\hline$B I G L A W$ & 0.065 & $2.87^{* * *}$ & 0.065 & $2.87^{* * *}$ \\
\hline$R A N K \_U N D E R W R I T E R$ & 0.002 & 1.51 & 0.002 & 1.49 \\
\hline Intercept & 3.052 & $9.30^{* * *}$ & 3.065 & $9.32^{* * *}$ \\
\hline F-test: & & & & \\
\hline $\begin{array}{l}S C I P O+ \\
S C I P O \times L O C K U P=0\end{array}$ & 0.060 & 0.75 & 0.055 & 0.66 \\
\hline Fixed Effects & Indust & Year & Indust & Year \\
\hline \# of Obs & & & & \\
\hline Adjusted $\mathrm{R}^{2}$ & & & & \\
\hline
\end{tabular}

Notes: All regressions include industry fixed effects, year fixed effects, and robust standard errors. ${ }^{* * *},{ }^{* *}$ indicate statistical significance at the 10,5, and 1 percent levels, respectively, based on two-sided t-tests. Variables are defined in Appendix A. 
TABLE 10

Results for Determinants of Supercharged IPOs Regression and Analyses Based on EntropyBalanced Samples of Supercharged and Traditional IPO Firms

Panel A: Results for Regression where Dependent Variable Is Supercharged IPO Indicator Variable (SCIPO)

\begin{tabular}{|c|c|c|c|}
\hline & Coefficient & Z-Statistic & \\
\hline$S I Z E_{P R E}$ & 0.074 & 1.68 & $*$ \\
\hline$P T I_{P R E}$ & 0.217 & 1.45 & \\
\hline$L E V_{P R E}$ & 0.335 & 3.03 & *** \\
\hline NetDTA $_{P R E}$ & 3.925 & 2.3 & $* *$ \\
\hline INTANGIBLES $S_{P R E}$ & 0.537 & 1.48 & \\
\hline$V C \_B A C K E D$ & -0.488 & -1.84 & * \\
\hline$P E \_B A C K E D$ & -0.062 & -0.34 & \\
\hline$B I G N$ & 0.216 & 1.06 & \\
\hline$B I G L A W$ & 0.283 & 1.74 & * \\
\hline RANK_UNDERWRITER & 0.000 & -0.05 & \\
\hline Intercept & -2.851 & -7.36 & *** \\
\hline Industry Indicators (5) & \multicolumn{2}{|c|}{ Yes } & \\
\hline \# of Obs & \multicolumn{2}{|c|}{1,211} & \\
\hline Pseudo $\mathrm{R}^{2}$ & \multicolumn{2}{|c|}{$18.45 \%$} & \\
\hline Area under the ROC Curve & \multicolumn{2}{|c|}{0.8285} & \\
\hline
\end{tabular}

Panel B: Results for OLS Regressions Based on Entropy-Balanced Samples, where IPO Offer Price (OFFER_PRICE) Is the Dependent Variable

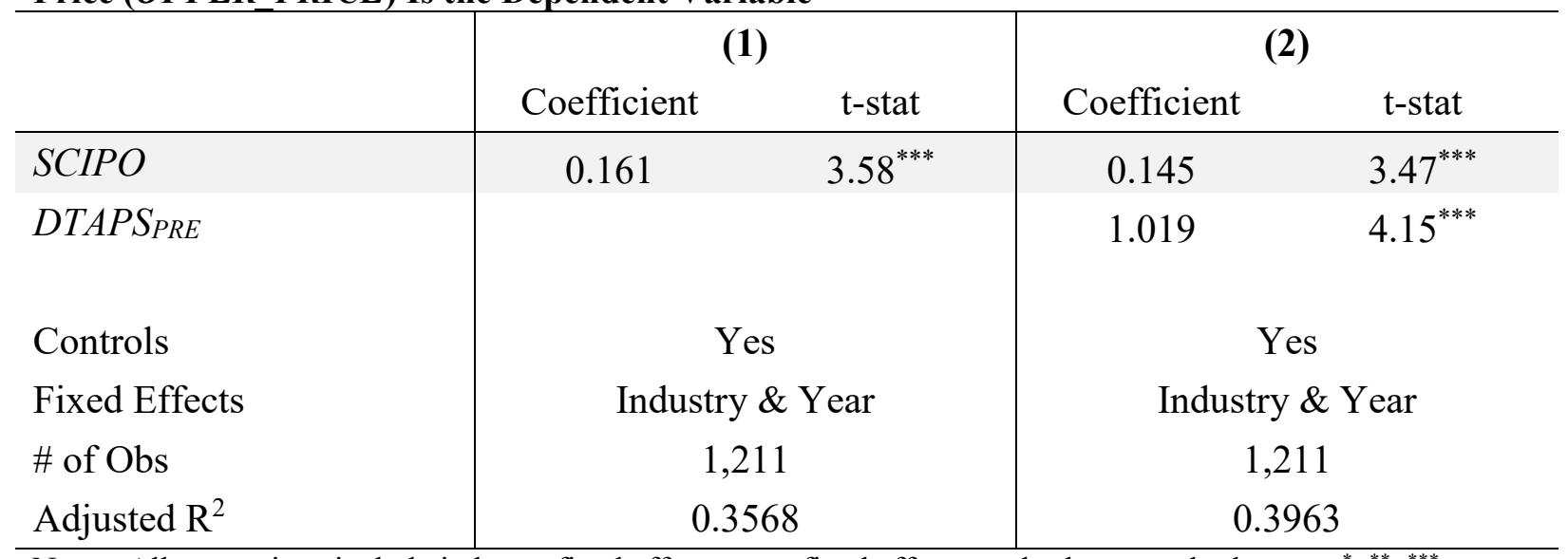

Notes: All regressions include industry fixed effects, year fixed effects, and robust standard errors. *, **, *** indicate statistical significance at the 10,5, and 1 percent levels, respectively, based on two-sided t-tests. Variables are defined in Appendix A. 
Panel C: Results for OLS Regressions Based on Entropy-Balanced Samples, where the Percent Change in Stock Price on the First Day of Trading (UNDERPRICING) Is the Dependent Variable

\begin{tabular}{|c|c|c|c|c|}
\hline & \multicolumn{2}{|c|}{ (1) } & \multicolumn{2}{|c|}{ (2) } \\
\hline & Coefficient & t-stat & Coefficient & t-stat \\
\hline SCIPO & 0.004 & 0.10 & 0.004 & 0.06 \\
\hline$D T A P S_{P R E}$ & & & 0.016 & 0.06 \\
\hline Controls & \multicolumn{2}{|c|}{ Yes } & \multicolumn{2}{|c|}{ Yes } \\
\hline Fixed Effects & \multicolumn{2}{|c|}{ Industry \& Year } & \multicolumn{2}{|c|}{ Industry \& Year } \\
\hline \# of Obs & \multicolumn{2}{|c|}{1,211} & \multicolumn{2}{|c|}{1,211} \\
\hline Adjusted $\mathrm{R}^{2}$ & \multicolumn{2}{|c|}{0.1944} & \multicolumn{2}{|c|}{0.1937} \\
\hline
\end{tabular}

Notes: All regressions include industry fixed effects, year fixed effects, and robust standard errors. ${ }^{*},{ }^{* *}$, indicate statistical significance at the 10, 5, and 1 percent levels, respectively, based on two-sided t-tests.

Variables are defined in Appendix A.

Panel D: Results for OLS Regressions Based on Entropy-Balanced Samples, where Proxies for Future Firm Performance Are the Dependent Variables

\begin{tabular}{|c|c|c|c|c|c|c|}
\hline & \multicolumn{2}{|c|}{$\begin{array}{c}\mathbf{( 1 )} \\
\text { Dependent Var }= \\
E B I T_{P O S T}\end{array}$} & \multicolumn{2}{|c|}{$\begin{array}{c}\text { (2) } \\
\text { Dependent } \mathrm{Var}= \\
S A L E S_{P O S T}\end{array}$} & \multicolumn{2}{|c|}{$\begin{array}{c}\mathbf{( 3 )} \\
\text { Dependent } \mathrm{Var}= \\
C F O_{P O S T}\end{array}$} \\
\hline & Coeff & t-stat & Coeff & t-stat & Coeff & t-stat \\
\hline SCIPO & 0.068 & $3.17^{* * *}$ & 0.071 & 0.87 & 0.055 & $1.91^{*}$ \\
\hline Controls & \multicolumn{2}{|c|}{ Yes } & \multicolumn{2}{|c|}{ Yes } & \multicolumn{2}{|c|}{ Yes } \\
\hline Fixed Effects & \multicolumn{2}{|c|}{ Industry \& Year } & \multicolumn{2}{|c|}{ Industry \& Year } & \multicolumn{2}{|c|}{ Industry \& Year } \\
\hline \# of Obs & \multicolumn{2}{|c|}{959} & \multicolumn{2}{|c|}{959} & \multicolumn{2}{|c|}{959} \\
\hline Adjusted $\mathrm{R}^{2}$ & \multicolumn{2}{|c|}{0.3434} & \multicolumn{2}{|c|}{0.6413} & \multicolumn{2}{|c|}{0.336} \\
\hline
\end{tabular}

